\title{
Deep drivers of mesoscale circulation in the central Rockall Trough
}

\author{
T. J. Sherwin, D. Aleynik, E. Dumont, and M. E. Inall \\ Scottish Association for Marine Science, Scottish Marine Institute, Oban PA37 1QA, UK \\ Correspondence to: T. J. Sherwin (toby.sherwin@sams.ac.uk)
}

Received: 5 September 2014 - Published in Ocean Sci. Discuss.: 25 November 2014

Revised: 25 March 2015 - Accepted: 13 April 2015 - Published: 12 May 2015

\begin{abstract}
Mesoscale variability in the central Rockall Trough, immediately west of the British Isles, has been investigated using a combination of ship-borne, underwater glider and gridded satellite altimeter measurements. Altimeter observations show that eddies and large-scale circulation cells are ubiquitous phenomena. They have horizontal length scales of order $100 \mathrm{~km}$ with vertical scales of over $1000 \mathrm{~m}$ and are associated with mean current speeds (over the upper $1000 \mathrm{~m})$ of $15 \pm 7 \mathrm{~cm} \mathrm{~s}^{-1}$. Monthly area averaged surface eddy kinetic energy (EKE) has substantial inter-annual variability, which at times can dominate a mean seasonal signal that varies from a maximum in May $\left(74 \mathrm{~cm}^{2} \mathrm{~s}^{-2}\right)$ to a minimum in October $\left(52 \mathrm{~cm}^{2} \mathrm{~s}^{-2}\right)$ and has increased gradually since 1992 at about $1.1 \mathrm{~cm}^{2} \mathrm{~s}^{-2}$ per year. This increase may be related to the retreat of the sub-polar gyre (SPG). A 5 month glider mission in the trough showed that the cyclonic component of EKE came from cold water features that are located over $1000 \mathrm{~m}$ below the surface. The surface currents from altimeters had similar magnitude to the drift currents averaged over $1000 \mathrm{~m}$ from the glider in the stratified autumn, but were half the deep water speed during late winter. Although the mesoscale features move in an apparent random manner, they seem to be constrained by submarine topography such as seamounts. Occasionally anti-cyclonic and cyclonic cells combine to cause a coherent westward deflection of the European slope current that warms the Rockall side of the trough. Such deflections contribute to the interannual variability in the observed temperature and salinity that are monitored in the upper $800 \mathrm{~m}$ of the trough. By combining glider and altimeter measurements it is shown that altimeter measurements fail to observe a $15 \mathrm{~cm} \mathrm{~s}^{-1}$ northward flowing slope current on the eastern side as well as a small persistent southward current on the western side. There is much to be gained from the synergy between satellite altimetry and in situ glider observations.
\end{abstract}

\section{Introduction}

The northern end of the Atlantic Ocean (south of the Greenland-Scotland Ridge) is dominated by a basinwide three-dimensional cyclonic interleaving of wind- and thermohaline-driven water masses known as the sub-polar gyre (SPG) (e.g. Bacon, 1998; Hakkinen and Rhines, 2009; Hátún et al., 2005; Pickart et al., 2003). Convective forcing drives its strongest currents in the deeper waters of the Labrador Sea and Irminger Basin in the west, but the influence of the gyre stretches across the Iceland Basin and into the Rockall Trough on its eastern side. Warm, salty surface water is carried northward through the basin and trough across the Greenland-Scotland Ridge and into the Nordic Seas (e.g. Hansen et al., 2010; Hansen and Østerhus, 2000). The complexity of the SPG is demonstrated by Tett et al. (2014), who analysed the transports produced by six global ocean reanalyses and found that a recent 50 year increase in the strength of the Atlantic Meridional Overturning Circulation (AMOC) south of the SPG was uncorrelated with the relatively steady exchange across the GreenlandScotland Ridge. This result would appear to undermine a basic assumption that convection at high latitudes drives an Atlantic thermohaline circulation. Understanding all aspects of the SPG is thus critical to studies of the global and local climate, and whilst progress has been made in defining the deep, cold southward flowing boundary currents in the western part, less is known about the currents and transports in the generally warmer and saltier water in the east.

Models of the SPG require an accurate representation of the exchange across their boundaries, which in turn depends on an accurate parameterisation of mixing and circulation in its various basins, including the Rockall Trough. In response to a need to systematically study the SPG, a major international oceanographic observation programme was estab- 


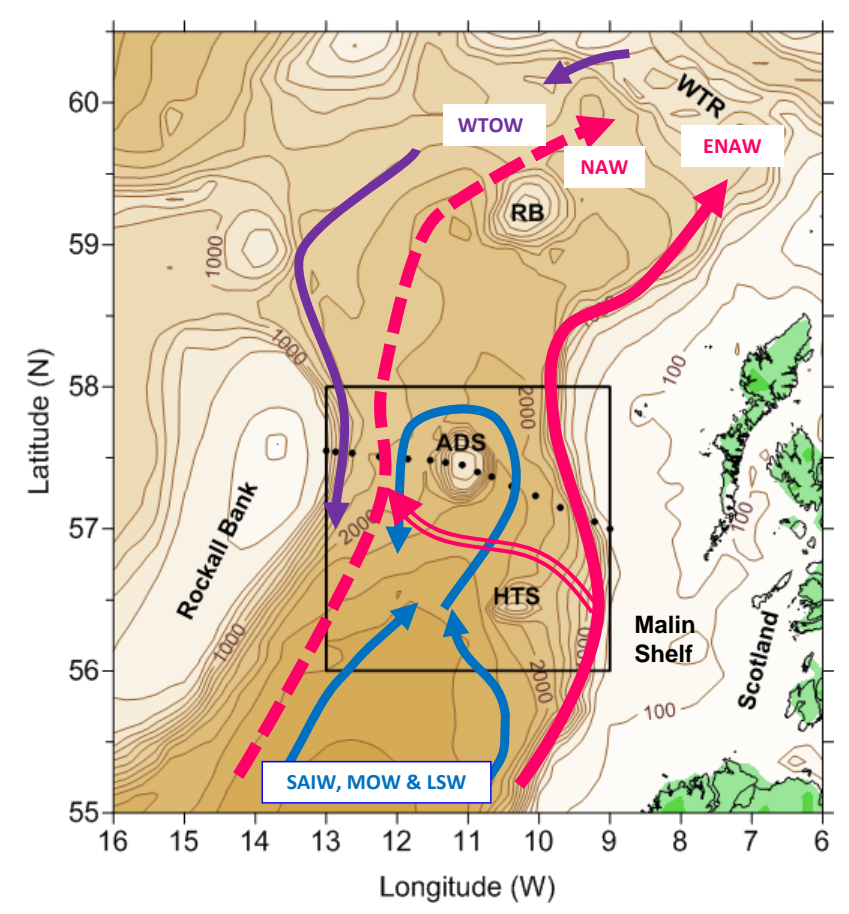

Figure 1. Map of the Rockall Trough with bathymetry (m) and the major currents. WTR: Wyville Thomson Ridge; RB: Rosemary Bank; HTS: Hebrides Terrace Seamount. Other acronyms are defined in the text. D340 stations are shown as a series of black dots. The red "tramway" is the alternative route of ENAW identified in this paper. The black box outlines the area that EKE is averaged over in Fig. 9.

lished in 2013 (O-SNAP, www.o-snap.org). One component of O-SNAP is the Ellett Line, a regular annual conductivity temperature depth (CTD) section across the Rockall Trough that has been sustained since 1975 .

In the winter of 2009 to 2010 the Scottish Association for Marine Science increased the sampling frequency by deploying an underwater glider, and the first new data points for the Ellett Line time series were published in Sherwin et al. (2012). By combining these glider data with gridded satellite altimetry ship-borne observations, new insights into the current field of the Rockall Trough have been derived.

\section{Background}

The Rockall Trough is an $800 \mathrm{~km}$ long by $200 \mathrm{~km}$ wide trench that lies to the west of the British Isles (Fig. 1). At its southern entrance $\left(53^{\circ} \mathrm{N}, 17^{\circ} \mathrm{W}\right)$ it is up to $3500 \mathrm{~m}$ deep, but it shallows towards the north to a depth of $1000 \mathrm{~m}$ at the foot of the Wyville Thomson Ridge $\left(8^{\circ} \mathrm{N}, 60^{\circ} \mathrm{W}\right)$, itself about $600 \mathrm{~m}$ deep. South of $58.5^{\circ} \mathrm{N}$ the western side of the trough is flanked by the Rockall-Hatton Plateau (minimum depth of order $100 \mathrm{~m}$ ), but further north this boundary is populated by a series of deep channels (to $1000 \mathrm{~m}$ ) and shallow banks that
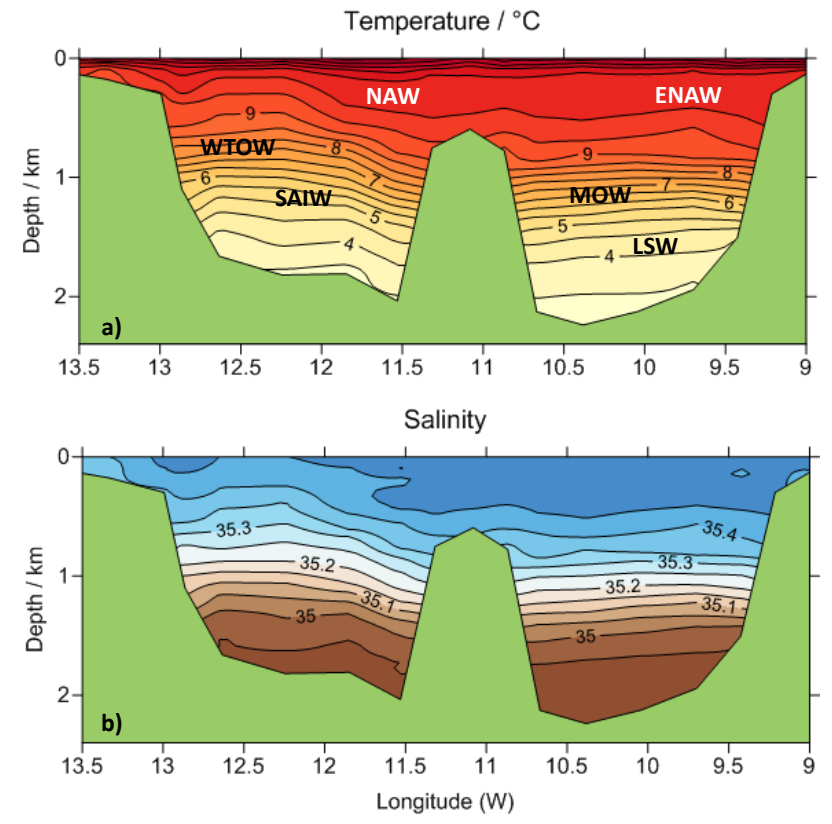

Figure 2. (a) Temperature and (b) salinity sections through the Anton Dohrn Seamount in mid-June 2009. Water masses are indicated, with those in black being much diluted at $56^{\circ} \mathrm{N}$. Kriging interpolation was used to map contours to the seabed. The approximate bathymetry is defined by the depth of each cast.

are less than $500 \mathrm{~m}$ deep. There are several seamounts in the northern part of the trough, the most important of which (for present purposes) are the steep sided Anton Dohrn Seamount (ADS) that rises to $500 \mathrm{~m}$ at $57.5^{\circ} \mathrm{N}, 11^{\circ} \mathrm{W}$ and the Hebrides Terrace Seamount at $56^{\circ} 30^{\prime} \mathrm{N}, 10^{\circ} 30^{\prime} \mathrm{W}$ (minimum depth $1000 \mathrm{~m})$.

The problems of quantifying and monitoring circulation on the eastern side of the SPG stem from (i) weak net transports with only moderate eastern boundary intensification and (ii) the presence of relatively strong mesoscale currents. The general distribution of the currents and water masses in the northern half of the trough (Fig. 1) is well documented (e.g. Ellett et al., 1986; Ellett and Martin, 1973; McCartney and Mauritzen, 2001). In the upper layers (to at least $600 \mathrm{~m})$ there is a slow north-eastward flow $(\sim 0.7 \mathrm{~Sv}$, or $0.7 \times 10^{6} \mathrm{~m}^{3} \mathrm{~s}^{-1}$ ) of relatively cool North Atlantic Water (NAW) originating in the North Atlantic Current (NAC) and including water from the sub-polar front in the western Atlantic (Holliday et al., 2000). This flow is enhanced along the eastern boundary by a slope current down to $500 \mathrm{~m}$, with a width of order $50 \mathrm{~km}$ and mean speeds of up to $\sim 20 \mathrm{~cm} \mathrm{~s}^{-1}$, in which about $3 \mathrm{~Sv}$ of warmer, salty Eastern North Atlantic Water (ENAW) from a more tropical source is found (Booth and Ellett, 1983; Holliday et al., 2000; Souza et al., 2001). At intermediate depths (say to $1000 \mathrm{~m}$ ) there is a mixture of Sub-Arctic Intermediate Water (SAIW) from deep in the NAC and Mediterranean Overflow Water (MOW) from the 

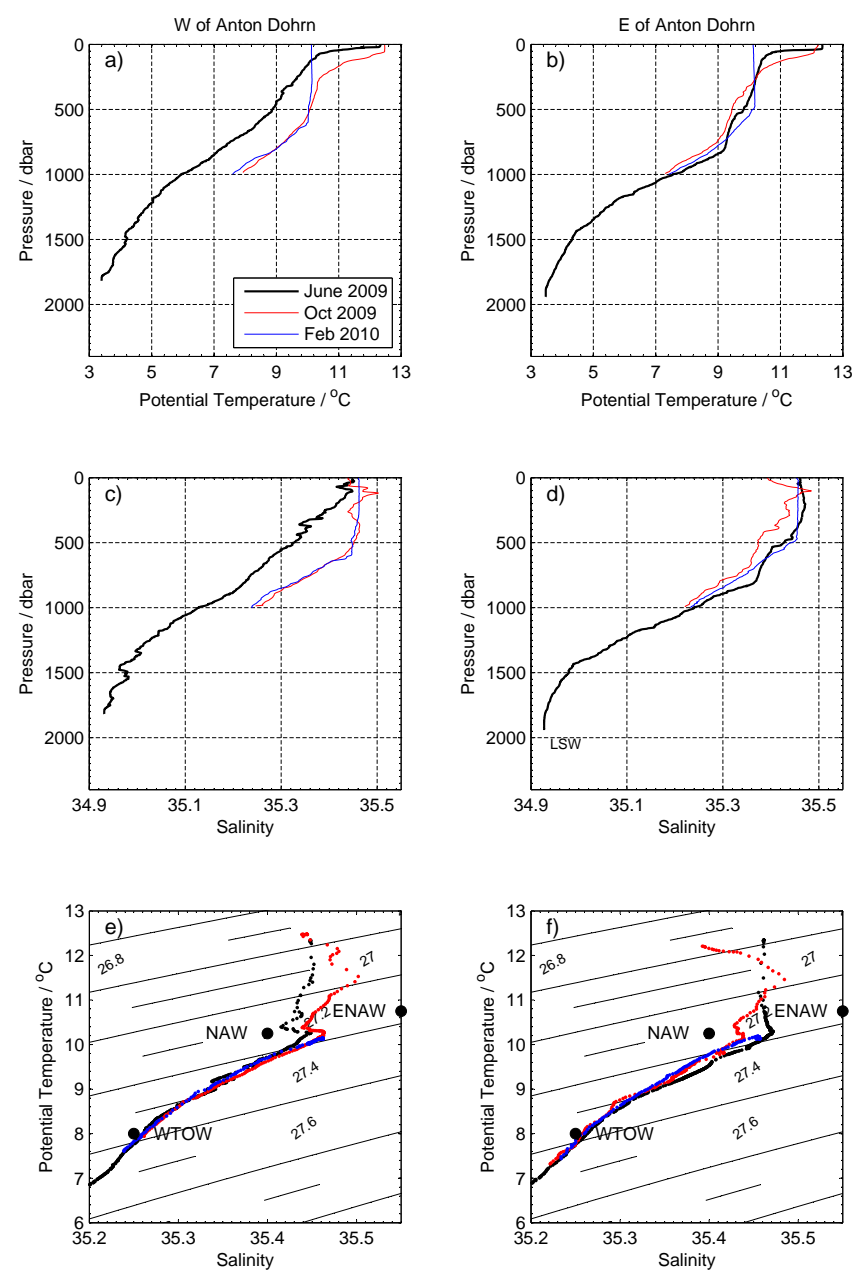

Figure 3. Temperature and salinity profiles and $\theta S$ plots either side of the Anton Dohrn Seamount from cruise D340 (full depth, black) and Mission 1 (to $1000 \mathrm{~m}$, red and blue). Glider data are averages of the up and down casts. For positions, see Fig. 8.

south (e.g. Reid, 1979; Ullgren and White, 2010) that over decadal timescales interact with each other and with Wyville Thomson Ridge Overflow Water (WTOW) coming from the north (e.g. Ellett and Roberts, 1973; Johnson et al., 2010). At deeper levels (down to about $1800 \mathrm{~m}$ ) low-salinity Labrador Sea Water (LSW) intermittently pulses into the trough from the south-west (Holliday et al., 2000), whilst deeper again is water with the signature of Antarctic Bottom Water (Figs. 2 and 3). The Ellett Line ship-borne CTD sections reveal that after 1995 there was a steady rise in temperature and salinity in the trough that is associated with a retreat of the SPG to the west (Hátún et al., 2005; Johnson et al., 2013), although since 2010 this trend appears to have reversed (Holliday et al., 2015).

Although at times mesoscale activity in the northern part of the Rockall Trough has been thought to be weak (e.g. Pollard et al., 1983), hydrographic observations during the JASIN experiment of the summer of 1979 to the west of
Rosemary Bank showed that this is not the case. A cyclonic mesoscale eddy with a diameter of $\sim 100 \mathrm{~km}$, and internal velocities of order $10 \mathrm{~cm} \mathrm{~s}^{-1}$, propagated westward through the observation area (at about $59.5^{\circ} \mathrm{N}$ ) with a translation speed of about $1.4 \mathrm{~km} \mathrm{day}^{-1}$ (Ellett et al., 1983). It is notable that this eddy was coherent to well below $1000 \mathrm{~m}$ and had a weak surface signature. Its direction of propagation and water composition indicated to the JASIN group that it was formed by the overflow of WTOW across the ridge.

A synthesis of current meter observations from north of $57^{\circ} \mathrm{N}$ by Dickson et al. (1986) revealed a maximum in eddy kinetic energy (EKE) levels at all depths (from current meters) in winter to spring that lagged the peak in wind stress. Subsequent surface drifter studies in the central and northern parts of the trough by Booth (1988) and Burrows et al. (1999) revealed clear evidence of mesoscale eddies. Booth (1988) identified three eddies: a large anti-cyclonic one south of this study area at $54^{\circ} \mathrm{N}, 15.5^{\circ} \mathrm{W}$ with a radius of $60 \mathrm{~km}$, a periodic timescale of up to 16 days and an orbital speed of up to $80 \mathrm{~cm} \mathrm{~s}^{-1}$; and two much smaller cyclonic ones, with periods of 1 to 2 days and orbital speeds up to $35 \mathrm{~cm} \mathrm{~s}^{-1}$ that rotated anti-cyclonically around the ADS. He attributed the source of these eddies to instability of the slope current near the Porcupine Bank and to Taylor column dynamics over the seamount respectively. More recently, Ullgren and White (2012) found 35 eddies over a 6 year period from 2001 in the southern part of the trough between $50^{\circ}$ and $56^{\circ} \mathrm{N}$ using satellite altimetry and mid-water ARGOS floats. Cyclonic eddies tended to enter along the track of the NAC and anti-cyclonic eddies were found along the path of the slope current and may have included Mediterranean Overflow Water. The eddies were typically slow moving and their cores had radii of $\sim 27 \mathrm{~km}$, and the floats had an orbital speed of $20 \mathrm{~cm} \mathrm{~s}^{-1}$. The energy sources of this motion are not certain, but EKE levels in the trough had a seasonal peak in spring, so they may have been wind forced.

More generally, there have been several large-scale studies of circulation of the North Atlantic as a whole based on archived data sets. Satellite altimetry (Heywood et al., 1994; Volkov, 2005) indicates enhanced levels of EKE in the Rockall Trough (order $100 \mathrm{~cm}^{2} \mathrm{~s}^{-2}$ ) that contrasts with the quiescent Rockall-Hatton Plateau. Surface drifter tracks (Fratantoni, 2001; Jakobsen et al., 2003) across the North Atlantic reveal a similar picture, with the latter finding that boundary currents were enhanced by wind stress in winter, which in turn seemed to lead to enhanced instability and the appearance of increased mesoscale activity in spring. A study of intermediate depth drifters (Argo floats, RAFOS drifters, for example) indicated EKE levels of order $20-40 \mathrm{~cm}^{2} \mathrm{~s}^{-2}$ at depths between 1500 and $1750 \mathrm{~m}$ in the southern part of the Rockall Trough (Lankhorst and Zenk, 2006).

To sum up, historical observations suggest that the Rockall Trough has a moderate level of EKE activity which ranges from a maximum of about $100 \mathrm{~cm}^{2} \mathrm{~s}^{-2}$ at the surface to about $25 \mathrm{~cm}^{2} \mathrm{~s}^{-2}$ at $1500 \mathrm{~m}$. There is evidence of a seasonal signal 


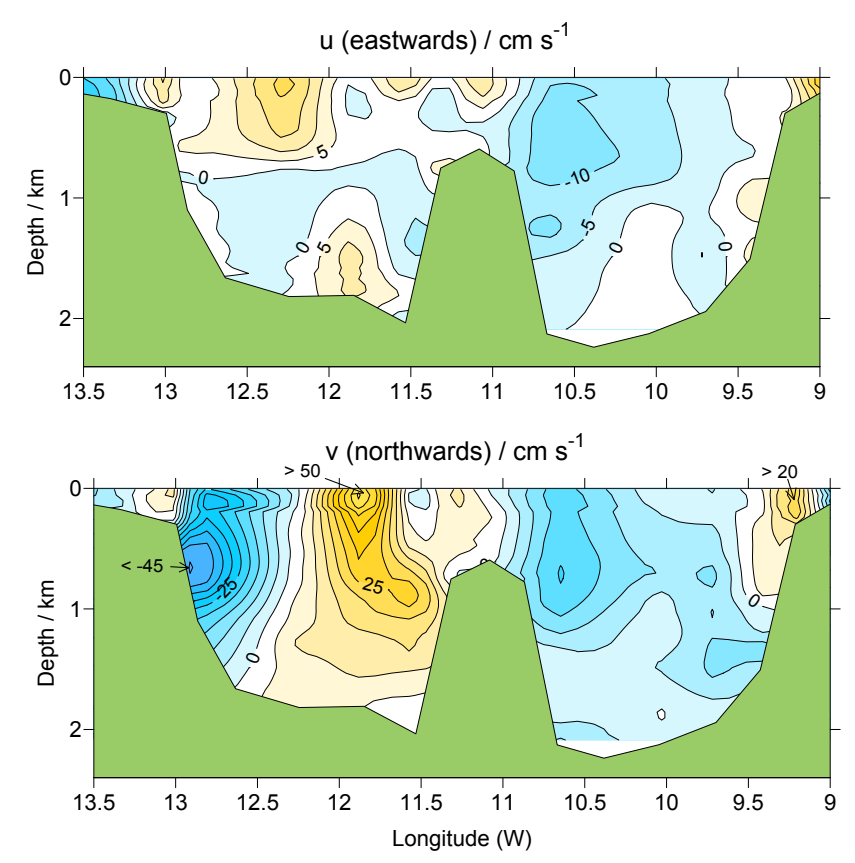

Figure 4. Full-depth LADCP sections of currents in mid-June 2009 along the Ellett Line. The upper panel shows zonal currents across the trough and the lower panel shows meridional currents. Tidal currents may be aliased in water less than $150 \mathrm{~m}$. Kriging interpolation was used to map contours to the seabed. The approximate bathymetry is defined by the depth of each cast.

with a maximum in spring or early summer that may be related to instabilities formed in the boundary currents.

In this study we look in detail at the mesoscale current field in the central part of the trough, focussing on a 12 month period between mid-2009 and mid-2010 to provide a more complete picture than has been possible to date of the timevarying three-dimensional structure of mesoscale currents in the trough, and their impact on the circulation and horizontal mixing of the trough. It will also explain why the mean temperature and salinity from the first glider mission appeared anomalously high (see Sherwin et al., 2012).

\section{Methods}

\subsection{Ship-borne CTD and LADCP}

The 2009 Ellett Line section of RRS Discovery cruise D340 (Sherwin et al., 2009) was conducted between 16 and 20 June, and provides a full depth picture of the temperature, salinity and velocity fields (Figs. 2-4). Profiles were measured with a stainless steel Seabird 911 CTD package that was suspended inside a 24 bottle rosette of $20 \mathrm{~L}$ water bottles and below which was attached a downward looking $300 \mathrm{kHz}$ lowered acoustic Doppler current meter (LADCP). The CTD system was lowered at typically $1 \mathrm{~m} \mathrm{~s}^{-1}$ and data were calibrated against water bottle samples. The LADCP data were processed using LDEO version IX.5 of the modified Visbeck routines (Thurnherr, 2010) which corrects velocity observations for the relative motions of the LADCPs to achieve a quoted accuracy of $<3 \mathrm{~cm} \mathrm{~s}^{-1}$ when two LADCPs are used. D340 did not have an upward looking LADCP, so individual observations were less accurate than this, but realistic profiles were achieved with smoothing applied over $50 \mathrm{~m}$. On some casts a titanium frame and simple CTD system without an LADCP were used, so the number of velocity profiles was less than the CTD ones.

\subsection{Satellite altimetry}

Weekly syntheses of merged gridded satellite altimeter data were downloaded for the period 14 October 1992-7 August 2013 from the Aviso website (www.aviso.oceanobs. com) which provides processed data from all altimeter missions for near real time applications and offline studies. During this period the trough was covered by the JASON 1 and 2 satellites (cycle time 10 days, track separation $120 \mathrm{~km}$ ) and the Envisat and ERS-2 satellites ( 35 days and $40 \mathrm{~km}$ ), which together provided a reasonably dense coverage of sea surface observations. Daily and weekly averages of sea level anomaly (SLA) were added to the CNES-CLS09 estimate for the mean dynamic topography (MDT) to produce an absolute dynamic topography (ADT) on a nominally $1 / 3^{\circ}$ Mercator grid (i.e. $\mathrm{ADT}=\mathrm{MDT}+\mathrm{SLA}$ ). The data supplied by Aviso had a meridional grid spacing of $20.7 \mathrm{~km}$ and a zonal spacing that ranged from $20.9 \mathrm{~km}$ at $55.5^{\circ} \mathrm{N}$ to $19.6 \mathrm{~km}$ at $58.5^{\circ} \mathrm{N}$. Instantaneous and mean surface geostrophic currents (eastward, northward as $u, v \mathrm{~cm} \mathrm{~s}^{-1}$ respectively) were derived by Aviso from the ADT and MDT using the thermal wind equation.

The MDT heights are based on the observations of the geoid over 4 years between 1993 and 1999 by the Gravity Recovery and Climate Experiment (GRACE), a satellite observation programme run by NASA. The horizontal resolution of the raw GRACE geoid $(200-300 \mathrm{~km})$ has been enhanced using observations of in situ currents and hydrography between 1993 and 2008, along with concurrent satellite altimeter observations, to achieve a global resolution of $1 / 4^{\circ}$ (Rio et al., 2011). Whilst this resolution would appear sufficient for the Rockall Trough, it will be shown below that the MDT does not resolve the narrow slope currents.

Although all velocity calculations have used the ADT, reservation about the accuracy of the MDT has led to the semantic difficulty of using an acronym that includes the word "absolute". Since the sea surface plots use an arbitrary mean level, the text tends to use the acronyms ADT and SLA interchangeably and the reader should not attach too much interpretation to their use. 
Table 1. Summary of the dives used in most of the calculations and transit plots described below and (bottom row) equivalent speeds from the Ellett Line section during D340. Drift and standard deviation speeds are the scalar mean values per transit. (W) and (E) indicate the direction of travel.

\begin{tabular}{llllrr}
\hline Transit & Dive nos & Start & End & $\begin{array}{r}\text { Glider drift } \\
\text { speed }\left(\mathrm{cm} \mathrm{s}^{-1}\right)\end{array}$ & $\begin{array}{r}\text { Aviso surface } \\
\text { speed }\left(\mathrm{cm} \mathrm{s}^{-1}\right)\end{array}$ \\
\hline $1(\mathrm{~W})$ & $235: 304$ & 18 Oct & 31 Oct & $16.3 \pm 7.6$ & $14.8 \pm 8.0$ \\
$2(\mathrm{E})$ & $304: 353$ & 31 Oct & 12 Nov & $15.2 \pm 7.0$ & $13.9 \pm 7.8$ \\
$3(\mathrm{~W})$ & {$[353: 370500: 532]^{\mathrm{a}}$} & 12 Nov & 29 Dec & $11.3 \pm 5.8$ & $14.1 \pm 3.6$ \\
$4(\mathrm{E})$ & $532: 592$ & 29 Dec & 13 Jan & $12.7 \pm 6.3$ & $8.8 \pm 4.4$ \\
$5(\mathrm{~W})$ & $592: 636$ & 13 Jan & 25 Jan & $15.5 \pm 7.3$ & $7.8 \pm 4.3$ \\
$6(\mathrm{E})$ & {$[636: 647673: 708]^{\mathrm{a}}$} & 25 Jan & 14 Feb & $17.3 \pm 6.1$ & $6.8 \pm 3.5$ \\
$7(\mathrm{~W})$ & $708: 742$ & 14 Feb & 23 Feb & $18.0 \pm 8.1$ & $9.9 \pm 4.3$ \\
$8(\mathrm{E})$ & $742: 780$ & 23 Feb & 5 Mar & $16.0 \pm 7.8$ & $8.4 \pm 3.3$ \\
& Average & & $15.3 \pm 7.0$ & $10.6 \pm 4.9$ \\
\hline D340 (LADCP) & - & Jun 2009 & & $17.0\left(20.2^{\mathrm{b}}\right)$ & 9.1 \\
\hline
\end{tabular}

a The gaps in transits 3 and 6 are explained in the text; ${ }^{\mathrm{b}}$ mean current speed in the top $50 \mathrm{~m}$ (other D340 speeds are averaged over $1000 \mathrm{~m})$.

\subsection{Underwater glider}

Continuous observations of temperature and salinity along with depth averaged "drift" current down to $1000 \mathrm{~m}$ were made by an underwater glider operated by the Scottish Association for Marine Science in an exercise to evaluate a way to increase the monitoring of temperature and salinity along the Ellett Line. The glider was deployed on 12 October 2009 on the Scottish Shelf at $56.56^{\circ} \mathrm{N}, 7.48^{\circ} \mathrm{W}$ and made its way westward over the shelf edge to deep water by 18 October (dive 235, Table 1). In the subsequent 4.5 months it completed eight transits across the trough between the $500 \mathrm{~m}$ isobaths along an (approximately) WNWESE track between $56.40^{\circ} \mathrm{N}, 9.05^{\circ} \mathrm{W}$ at the edge of the shelf to $57.22^{\circ} \mathrm{N}, 12.52^{\circ} \mathrm{W}$ on the eastern flank of Rockall (about $250 \mathrm{~km}$ apart, Fig. 5), with each round trip taking about 4 weeks. It was finally recovered on 9 March 2010 near the shelf edge following a mechanical failure.

The glider (SG156) was a battery operated long-range autonomous underwater vehicle constructed by Seaglider Fabrication, University of Washington (Eriksen et al., 2001). Its descending and ascending vertical velocities were typically $10 \mathrm{~cm} \mathrm{~s}^{-1}$, so it took about $6 \mathrm{~h}$ to complete a full dive, during which time it travelled about $5.5 \mathrm{~km}$ against the ambient current at a horizontal speed of roughly $25 \mathrm{~cm} \mathrm{~s}^{-1}$. Its principal oceanographic instrument was an unpumped version of the Seabird SBE41 conductivity-temperature $(C \theta)$ system that was modified to minimise power consumption. Up to dive 476 (14 December) $C \theta$ was measured at $10 \mathrm{~s}$ (or about $1 \mathrm{~m}$ ) intervals down to $30 \mathrm{~m}$, then every $30 \mathrm{~s}$ to $200 \mathrm{~m}$ and every $60 \mathrm{~s}$ to $1000 \mathrm{~m}$. For the rest of the mission the frequencies became every $5 \mathrm{~s}$ to $100 \mathrm{~m}, 10 \mathrm{~s}$ to $500 \mathrm{~m}$ and $60 \mathrm{~s}$ to $1000 \mathrm{~m}$. Even though the vertical velocity is small, salinity spiking is a potential problem with the unpumped SBE41 when the glider travels through a pycnocline. Lag corrections

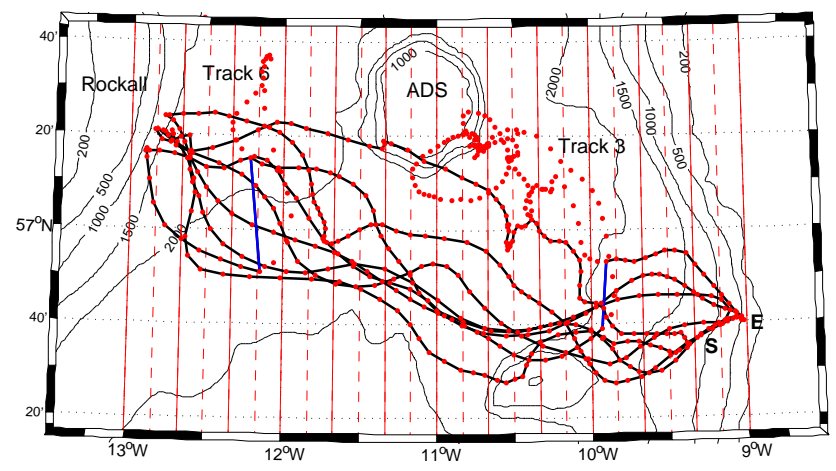

Figure 5. Glider track in the Rockall Trough from 18 October 2009 (S) to 5 March 2010 (E). Red dots are the dive positions. The black track connects those points used for averaging, with the blue lines connecting the gaps in tracks 3 and 6 (see Table 1 and Figs. 6 and 7). Vertical red lines delimit the $20^{\prime}$ (plain) and $10^{\prime}$ (dashed) zonal averaging bins. Isobaths are in $\mathrm{m}$.

are applied before salinity is computed from the raw data (e.g. Perry et al., 2008) and extensive tests were undertaken to assess the magnitude of the problem here (for example, by comparing ascending and descending temperature - salinity, or $\theta S$, plots). For the most part the up and down profiles were very similar, probably because sharp pycnoclines in the water column are absent during winter (blue profiles in Fig. 3). The October profiles (red in Fig. 3) suggest salinity spiking in the seasonal thermocline, but as the up and down profiles of $\theta$ and $S$ were similar, the sharp changes in the $\theta S$ gradient, which are also present in the D340 profile west of the ADS in June, are just as likely to have been due to water mass interleaving. The overall accuracy of the salinity observations are confirmed by the coincidence of glider and D340 $\theta S$ profiles below $10^{\circ} \mathrm{C}$ in Fig. 3. Furthermore, there was little evidence 

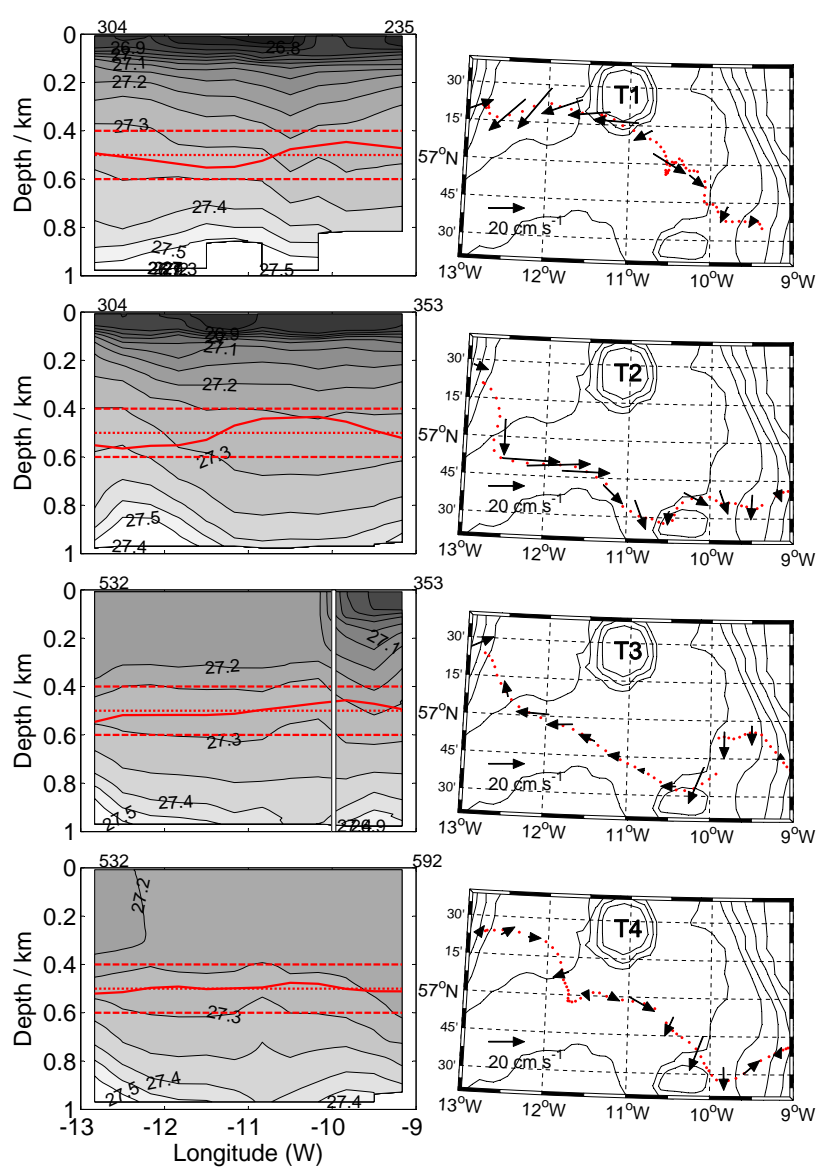

Figure 6a. Summary of observations from each of transits 1 to 4 . LH column: density anomaly sections $\left(\mathrm{kg} \mathrm{m}^{-3}\right)$ to $1000 \mathrm{~m}$ along the dotted track shown in the accompanying map. Also, the SLA (plain red line) is plotted as $\mathrm{cm}$ about $500 \mathrm{~m}$ (dotted red line), with the dashed red lines showing heights of $\pm 10 \mathrm{~cm}$. RH column: glider drift velocity vectors. All dive data (dotted red line) were averaged into $20^{\prime}$ bins before plotting. The labels "T1"-“T4" over the ADS in the RH column identify transits 1 to 4 ; see also Table 1.

of fouling on recovery, and pre- and post-mission CTD calibrations by Seabird Electronics indicated that there had been negligible drift in any of the sensors.

The surface positions of the glider were accurately determined from GPS fixes. Dive averaged ambient current velocities (or "drift" velocities) were computed using an algorithm based on a theoretical model of the glider's hydrodynamic performance through the water, which determines the difference between the expected and measured surfacing positions at the end of each dive. However, this calculation is sensitive to the accuracy of the glider's internal compass, and in post-processing it was found that a significant difference existed in the mean drift velocity measured during the eastward and westward transitions of the trough (about 7 and $10 \mathrm{~cm} \mathrm{~s}^{-1}$ southward respectively). Theoretical tests of possible error scenarios demonstrated that such a difference can
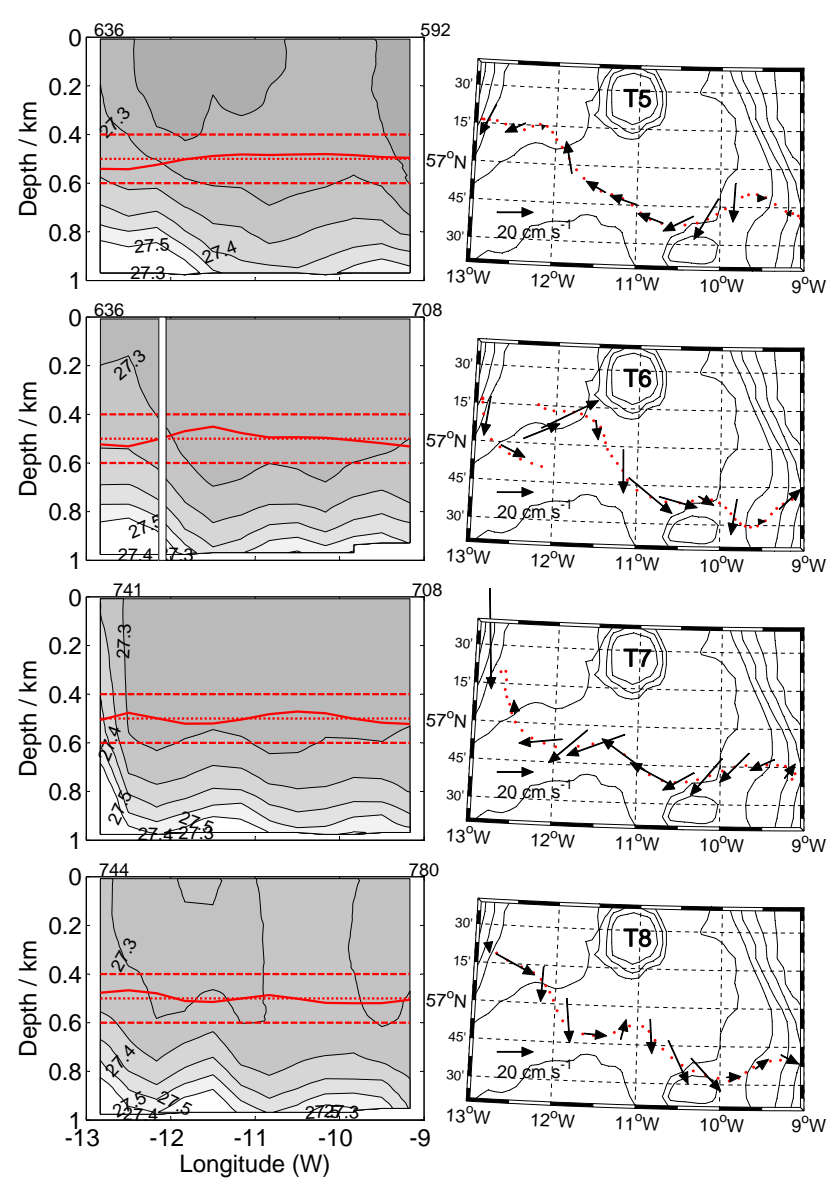

Figure 6b. Same as Fig. 6a but for tracks 5-8 (“T5”-“T8”).

be explained by a non-linear error in the compass measurements (a similar error has been reported by Merckelbach et al., 2008, for a different glider system). As a result, it was not possible to determine basin-wide transport. Other theoretical tests, however, indicated that the faster local eddy currents were reasonably well measured.

\subsection{Data analysis}

The spatial mean EKE in the central Rockall Trough between latitudes $56^{\circ}$ and $58^{\circ} \mathrm{N}$ and longitudes $9^{\circ}$ and $13^{\circ} \mathrm{W}$ was computed from the ADT currents as

$\mathrm{EKE}=\frac{(\operatorname{var} u+\operatorname{var} v)}{2}$,

where var is the variance at each grid point. Error in the mean of $N$ observations of EKE (err) was computed as

$\operatorname{err}=\frac{\mathrm{SD}(\mathrm{EKE})}{\sqrt{N}}$,

where SD is the standard deviation of the observations.

For Table 1 and Fig. 6 glider data from a specific transit of the trough were averaged into $10^{\prime}$ longitude (about $10 \mathrm{~km}$ ) 
wide meridional bins (see Fig. 5). The mean positions of the dives within a bin were then computed and the values of other data were determined by interpolating horizontally to the centre positions of the bins. The mean transit speeds and their standard deviations were derived by averaging individual speeds from the dives listed in Table 1. Density anomalies, shown as $\sigma_{\mathrm{t}}$ in Fig. 6, from each downward and upward dive were averaged into $5 \mathrm{~m}$ vertical bins and then smoothed in the vertical with a $25 \mathrm{~m}$ half-width Hamming filter before they were averaged into $20^{\prime}$ longitudinal bins for presentation.

The glider track deviated significantly from the intended transit on two occasions and data collected between 16 November and 20 December (Transit 3, when it had to be piloted out of a strong opposing current and communication was then lost for a while) and between 28 January and 4 February (Transit 6, when it was directed to investigate a potential eddy) have been omitted from the analysis (see Table 1). In making the bin averages no allowance was made for these gaps, even though they were quite extensive. Although the gap in Transit 3 lasted about 5 weeks, both density sections appear sufficiently continuous (Fig. 6) that the discontinuity in the data is unlikely to have compromised the general findings.

It is possible to compare the different Aviso and glider data sets directly by deriving equivalent time series. This was achieved by interpolating the 3-D (in space and time) fields of ADT and surface currents to match the time and position of individual glider observations. This time series was then processed and averaged in the same way as the glider data.

\subsection{Compatibility issues between glider and altimeter observations}

Mission 1 was conceived before gliders had become proven platforms in the North Atlantic and its success during a winter deployment was a stimulus for further uptake of gliders in the UK. There are especial challenges to analysing glider data, because they are slow moving vehicles and in a strong mesoscale current field their frame of reference is constantly moving. At first sight it would appear that data from a vehicle that takes about 2 weeks to cross the Rockall Trough would be incompatible with those from a satellite that every 2 weeks makes a single instantaneous measurement of SLA along a line that will usually be at least $10 \mathrm{~km}$ from the glider. The problem is further compounded by the fact that these length scales and timescales are comparable to those of the mesoscale currents that dominate the central Rockall Trough.

Hátún et al. (2007) combined glider and altimeter data to describe the structure of an anti-cyclonic eddy in the Labrador Sea, and Martin et al. (2009) used altimetry and repeated glider passes to analyse a long lasting stationary eddy in the Gulf of Alaska. In Mission 1 the glider tended to be carried in the faster currents that flowed around cyclones rather than through them (see Fig. 7 and the video in the Supplement), so a comparison of the structure of different eddies was not undertaken. Instead we have chosen to look at the general nature of the mesoscale eddy field. (Incidentally, the few cloud-free satellite observations of the surface showed minimal horizontal variation in winter temperatures and did not reveal the distribution of the deep eddy field.)

\section{Background observations}

\subsection{The evolution of temperature and salinity}

During June 2009 the seasonal thermocline was well established in the upper $100 \mathrm{~m}$ of the water column and there was clear evidence in the salinity signal of the influence of the slope current, in the upper $500 \mathrm{~m}$ on the eastern side, spreading across to the centre of the trough (Fig. 2). The deep thermocline (about $7.5^{\circ} \mathrm{C}$ ) which was located at about $800 \mathrm{~m}$ to the west of the ADS descended to about $1000 \mathrm{~m}$ on its eastern side (Figs. 2 and 3). The deep part of the water column was marked by gradual decreases in temperature and salinity with depth.

Seasonal warming and freshening of the surface layers on both sides of the trough persisted until October, but after that stratification weakened so that by February the upper $500 \mathrm{~m}$ was uniformly mixed. By and large the profiles of $\theta$ and $S$ in the upper $1000 \mathrm{~m}$ on the eastern side of the trough were well behaved and almost equally mixed between NAW in the centre of the trough and the more saline ENAW. To the west of the seamount, away from the influence of the shelf edge current, the changes in the profile appeared more dynamic, with an apparent interleaving between ENAW and the cooler and fresher NAW. Between October and February, and below about $200 \mathrm{~m}$, this side of the trough also experienced remarkable increases in both $\theta$ and $S$ as NAW appeared to be forced down by as much as $800 \mathrm{~m}$. A reason for these increases is discussed later.

\subsection{The velocity field during Discovery cruise D340}

The directly observed full-depth LADCP sections (Fig. 4) dispel any notion that the currents in waters of the central trough are either slow or vertically uniform. There was a fast southward flowing current (up to $45 \mathrm{~cm} \mathrm{~s}^{-1}$ ) along the slope of the Rockall Bank that is much stronger than the Aviso equivalent. There is a suggestion of an extensive feature that filled the space west of the ADS, which manifested itself in a pronounced surface depression of the SLA running down the western side of the trough. The sea surface had a particularly steep zonal gradient on the western side of the ADS (Fig. 8), which complemented the westward uplift of the deep pycnocline centred on $900 \mathrm{~m}$ (Figs. 2 and 3) and the strong in situ meridional currents (Fig. 4). The directly observed current of more than $25 \mathrm{~cm} \mathrm{~s}^{-1}$ that flowed northward along the upper edge of the Malin Shelf appears, surprisingly, as a weak 


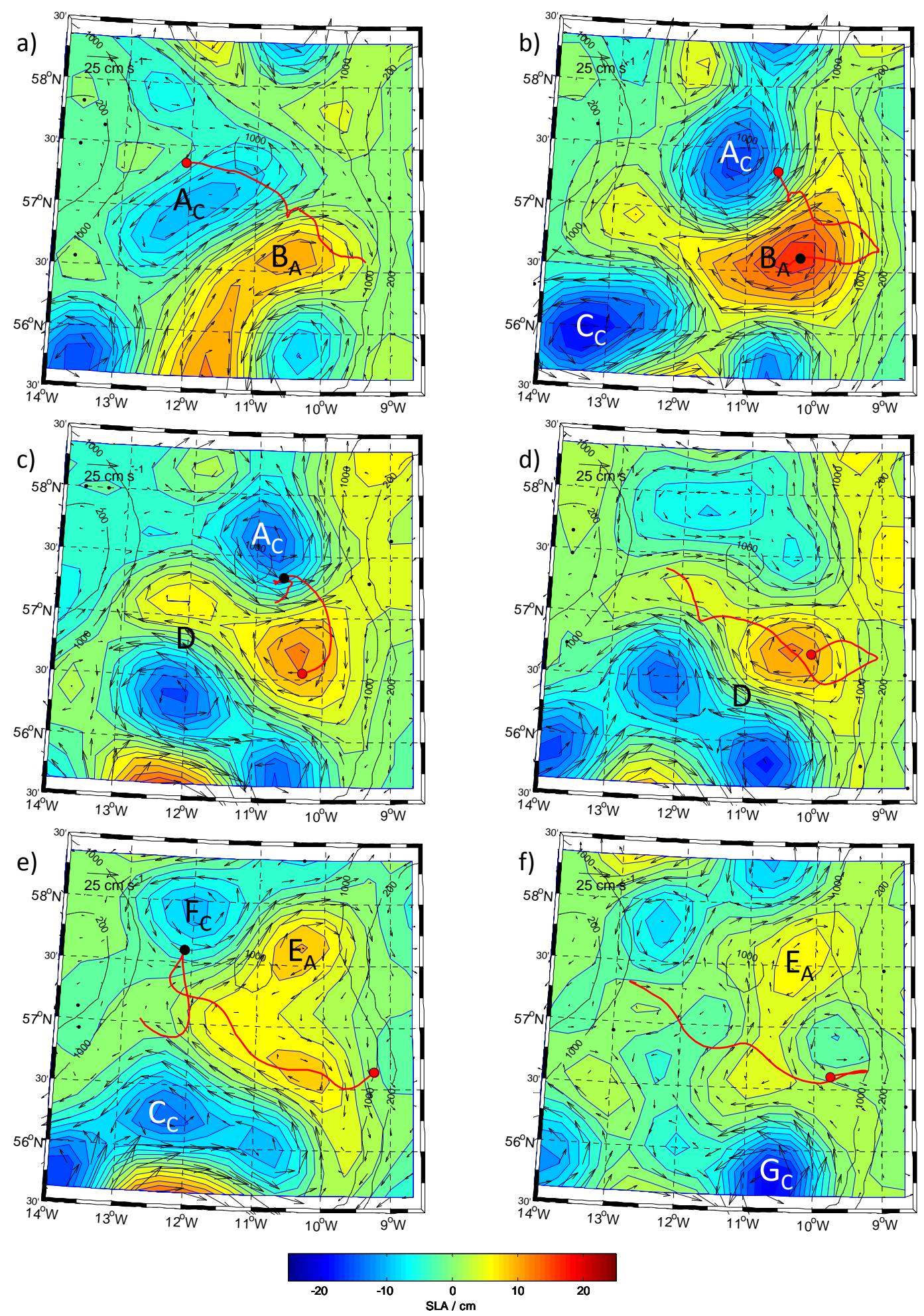

Figure 7. Snapshots of SLA and associated surface velocities (scaled by the $25 \mathrm{~cm} \mathrm{~s}^{-1}$ arrow in the top left-hand corner) sampled every 27 days during Mission 1. (a) 20 October 2009; (b) 16 November 2009; (c) 13 December 2009; (d) 9 January 2010; (e) 5 February 2010; (f) 4 March 2010. Red lines are the track of the glider for 9 days before and after each snapshot (where appropriate), with the head indicating the end position. The black dots show the position of dives used to investigate the $\theta S$ profiles of individual eddies (see Fig. 10). Each panel shows the anomaly about the area monthly mean to eliminate the colour shift due to the seasonal change in mean steric height. Isobaths are in $\mathrm{m}$. 


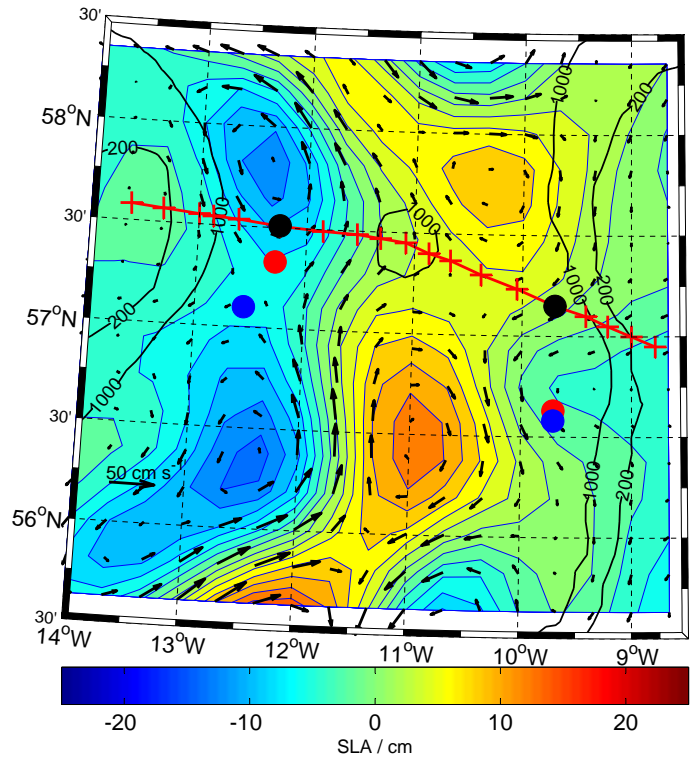

Figure 8. SLA and associated surface velocities (scaled by the $50 \mathrm{~cm} \mathrm{~s}^{-1}$ arrow near the bottom of the left side) on 18 June 2009. In red is the track of D340 with the positions of CTD profiles shown as " + ". The dots are the positions of the profiles either side of the ADS in Fig. 3 shown as black (June 2009), red (October 2009) and blue (February 2010). Isobaths are in $\mathrm{m}$.
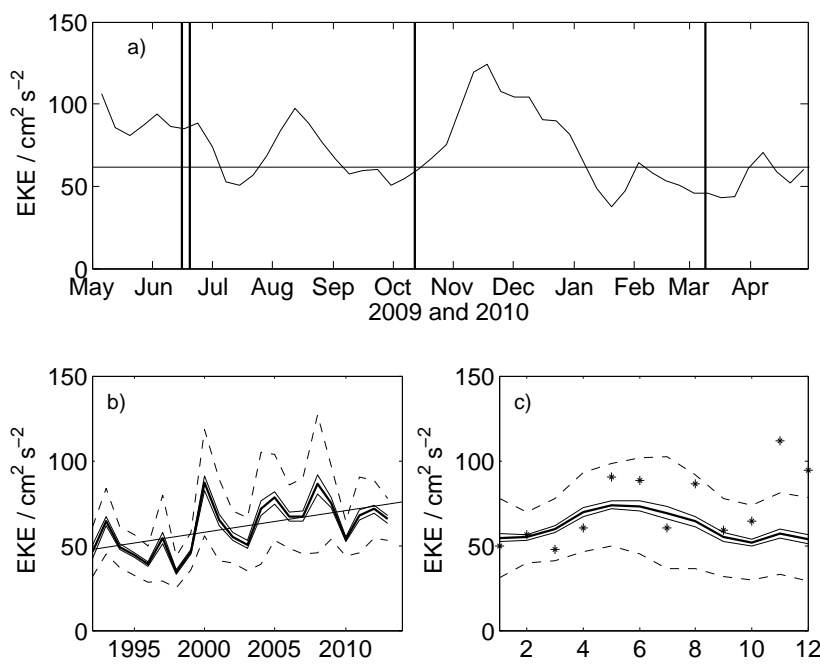

Figure 9. Mean EKE $\left(\mathrm{cm}^{2} \mathrm{~s}^{-2}\right)$ in the area bounded by $56^{\circ} \mathrm{N}$, $13^{\circ} \mathrm{W}$ and $58^{\circ} \mathrm{N}, 9^{\circ} \mathrm{W}$ (see Fig. 1) from altimetry. (a) Weekly EKE from 1 May 2009 to 30 April 2010. Vertical lines mark the times of the Ellett Line section (June 2009) and the start and end of glider Mission 1 (October 2009 and March 2010). (b) Weekly averages binned by year with the annual mean (thick line), bounded by the error in the mean (thin lines) and standard deviation (dashed lines). The straight line is the trend $\mathrm{EKE}=1.1 \times$ (year number $)-2100$; (c) as (b) but binned by month and without a trend line. Asterisks show the monthly averages between May 2009 and May 2010. southward flowing surface current by Aviso. The poor comparisons at the boundaries give a strong impression that the meridional ADT surface currents are badly represented at the edges of the Rockall Trough. This point will be taken further with the glider observations.

\subsection{Temporal variations in eddy kinetic energy}

The monthly means of the weekly averaged surface EKE in the central Rockall Trough (see box in Fig. 1) from Aviso gridded altimetry have increased at a rate of $1.1 \mathrm{~cm}^{2} \mathrm{~s}^{-2}$ per year since 1992 (Fig. 9b) with an inter-annual linear correlation coefficient of $R=0.65$. The reason for this long upward trend is not clear and a brief examination of the correlation with two candidate explanations was made. The oscillations in the North Atlantic Oscillation (e.g. Hurrell, 1995) for the years 1994-2013, acting as a surrogate for the strength of the wind stress, had a very weak negative correlation with EKE $(R=-0.2)$ with a high probability that this correlation is by chance $(p=0.5)$. Increases in the mean temperature and salinity in the upper $800 \mathrm{~m}$ from Ellett Line data between 1975 and 2010 had a stronger correlation $(R=0.49)$ with a low probability of chance $(p=0.05)$. High temperature and salinity are associated with a weak SPG (Hátún et al., 2005; Johnson et al., 2013), so it is possible that the increase in EKE is related to the westward retreat of the SPG in the northern Atlantic.

During the period May 2009 to April 2010, which covers the in situ observations described here, mean surface EKE levels $\left(66 \mathrm{~cm}^{2} \mathrm{~s}^{-2}\right)$ were about $11 \mathrm{~cm}^{2} \mathrm{~s}^{-2}$ larger than the long-term average. EKE was relatively high in June 2009 (about $84 \mathrm{~cm}^{2} \mathrm{~s}^{-2}$ ), although the highest level for the 12 months was over $100 \mathrm{~cm}^{2} \mathrm{~s}^{-2}$ in the middle of November 2009 (Fig. 9a). This latter peak occurred after a steady increase from about $55 \mathrm{~cm}^{2} \mathrm{~s}^{-2}$ at the start of the mission and was much more than a standard deviation away from the mean levels for November and December (Fig. 9c). It was followed by a steady decline to about $40 \mathrm{~cm}^{2} \mathrm{~s}^{-2}$ by the middle of January. Thus, in the 12 months from May 2009 to April 2010 the seasonal variation in EKE levels was anomalous compared the long-term average, where the peak occurs in May $\left(67 \mathrm{~cm}^{2} \mathrm{~s}^{-2}\right)$ and is at a minimum in October $\left(45 \mathrm{~cm}^{2} \mathrm{~s}^{-2}\right.$, Fig. $\left.9 \mathrm{c}\right)$.

\subsection{The evolution of SLA and surface currents during the glider mission}

As the glider tracks and SLA maps show (Figs. 5 and 7), the surface waters of the central Rockall Trough were continually disturbed by slow moving eddies and other mesoscale motions. Early in Mission 1 (on 20 October) an elliptical cell with a cyclonic circulation and a NE-SW major axis diameter of about $200 \mathrm{~km}$ occupied the deep water immediately SW of the ADS $\left(\mathrm{A}_{\mathrm{C}}\right.$, Fig. 7a), whilst immediately to the south of it lay an anti-cyclonic circulation of similar size 
$\left(\mathrm{B}_{\mathrm{A}}\right)$. A strong east to north-eastward current $\left(>20 \mathrm{~cm} \mathrm{~s}^{-1}\right)$ marked the boundary between them. During the first part of November, $A_{C}$ moved NE onto the seamount, where it intensified and seemed to become anchored until the middle of December, with a circular diameter of about $100 \mathrm{~km}$ and current speeds in excess of $20 \mathrm{~cm} \mathrm{~s}^{-1}$ (Fig. $7 \mathrm{~b}$ and c). Meanwhile, $\mathrm{B}_{\mathrm{A}}$ drifted eastward to the north of the Hebrides Terrace Seamount and a cyclonic cell (or eddy) started to drift into the picture from the southwestern corner $\left(\mathrm{C}_{\mathrm{C}}, \mathrm{Fig} .7 \mathrm{~b}\right)$. By the middle part of November a westward flowing current with maximum surface speeds in excess of $30 \mathrm{~cm} \mathrm{~s}^{-1}$ had formed in the southern part of the region (D). From then on the pattern of alternating cyclonic and anti-cyclonic eddies persisted throughout December (Fig. 7c), whilst they slowly lost energy until by 9 January average EKE in the region had weakened to $<50 \mathrm{~cm}^{2} \mathrm{~s}^{-2}$ (Figs. $7 \mathrm{~d}$ and $9 \mathrm{a}$ ). Nevertheless, these cells were still sufficiently intense to be able to drive a pronounced anti-cyclonic circulation westward across the trough between the two seamounts. From then on mesoscale activity increased a little so that by 5 February an anti-cyclonic circulation $\left(\mathrm{E}_{\mathrm{A}}\right)$, which may have evolved from $\mathrm{B}_{\mathrm{A}}$, had become trapped on or close to the ADS with current speeds only little less than the earlier $A_{C}$. At the same time the broad cyclonic circulation, $\mathrm{C}_{\mathrm{C}}$, had become established in the southern part of the region (Fig. 7e) and a new cyclonic eddy $\left(\mathrm{F}_{\mathrm{C}}\right)$ had appeared to the north-west of the ADS. Finally, by the start of March, $\mathrm{E}_{\mathrm{A}}$ had weakened a little above the ADS, whilst $C_{C}$ had disappeared and a new cyclonic eddy, $\mathrm{G}_{\mathrm{C}}$, had appeared close to the Malin Shelf edge between the ADS and the Hebrides Terrace Seamount.

Overall, the mesoscale motions in the deep water of the Rockall Trough seemed to be distributed in a fairly arbitrary pattern, although the circulations were arranged like gears in a pattern of anti-cyclonic/cyclonic cells. It is intriguing that both anti-cyclonic and cyclonic cells were able to occupy the top of the ADS, and it appears that the precise sense of circulation was determined more by the regional arrangement of the cells than by a local dynamic balance formed by the seamount itself. The vertical extent of these surface cells is described below.

A word of caution is necessary here. Later analysis that questions the validity of the background MDT in the Rockall Trough will throw doubt on the intensity on the anticyclonic circulations between the ADS and the Hebrides Terrace Seamount.

\section{Sub-surface glider observations winter 2009/2010}

Satellite altimeter observations of ADT and surface velocity give valuable information about the spatial and temporal scales of mesoscale variability in the Rockall Trough, but they provide a poor representation at boundaries and cannot reveal detail of the structure below the surface. Ship-borne sections such as those of D340 help to address these omis- sions, but are of necessity rare. By contrast, the underwater glider provides measurements of the density structure and velocity field that through the use of repeated sections help to construct a more complete picture of the variability below the surface.

\subsection{Glider profiles and drift currents}

It is quite difficult to navigate a glider precisely in a field of apparently random mesoscale currents that have a similar speed to its forward velocity. During Mission 1 the glider encountered ambient current speeds of over $24 \mathrm{~cm} \mathrm{~s}^{-1}$ in $25 \%$ of the dives, and at such times it might either be stopped dead, forced sideways or backwards, or race forward (hence the uneven spacing of the dive positions in Figs. 5 and 6). As a precaution (since this was its first mission) the glider was kept outside the $500 \mathrm{~m}$ isobath so that it did not measure the strength of the slope currents in the shallower water on either side of the trough. The original plan to pass across the top of the ADS along the Ellett Line route was abandoned after Transit 4 because the opposing currents near the seamount were too strong in the early part of the mission.

\subsection{Changes in temperature and salinity profiles across the trough}

At the beginning of Mission 1 the surface temperature and salinity at the shelf edge were about $12.6^{\circ} \mathrm{C}$ and 35.45 respectively (Fig. 3), fractionally warmer and fresher than that observed by $\mathrm{D} 340$ on 19 June $\left(12.3^{\circ} \mathrm{C}\right.$ and 35.47$)$. The temperature and salinity sections of the upper $200 \mathrm{~m}$ from Transit 1 were generally similar to those from D340. Over winter, between mid-October 2009 and the end of February 2010, surface stratification was gradually eroded and deepened so that by March the upper $500 \mathrm{~m}$ was almost isothermal and isohaline (Figs. 3 and 6). By contrast, the $\theta S$ profiles below about $600 \mathrm{~m}\left(9.5^{\circ} \mathrm{C}\right.$ and 34$)$ were very similar apart from vertical displacement due to the mesoscale motions, and are typical of Ellett Line profiles, which contain WTOW at intermediate depths (Johnson et al., 2010). In many transits the near-surface isopyncals were roughly horizontal, whereas those deeper in the water column (below about $600 \mathrm{~m}$ or $\sigma_{\mathrm{t}} \sim 27.3 \mathrm{~kg} \mathrm{~m}^{-3}$ ) had large and uneven variations in depth (with undulations up to $200 \mathrm{~m}$ high and $50 \mathrm{~km}$ wide) across the trough.

Over the course of the mission many of the changes in the track of the glider visually correlated with the ambient drift velocities and the undulating depth of the deep isopycnals (Fig. 6). (These correlations were observed to steadily evolve in real time as the plots from successive dives were updated on the mission console.) There also appears to be an inverse correlation between the depth of the SLA and the height of the deep isopycnals along the glider track. Mesoscale gradients of the deeper (rather than shallower) isopycnals of the trough were associated with depth mean current speeds mea- 

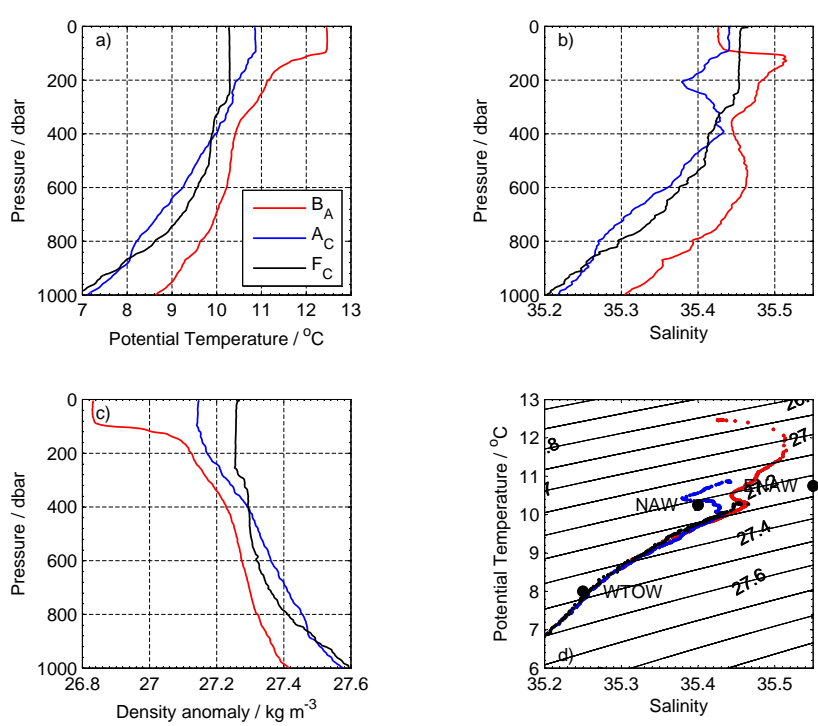

Figure 10. (a) Temperature, (b) salinity and (c) density anomaly profiles from the edge of cyclonic eddies $\mathrm{B}_{\mathrm{A}}, \mathrm{A}_{\mathrm{C}}$ and $\mathrm{F}_{\mathrm{C}}$ (see Fig. 7). (d) Equivalent $\theta S$ profiles.

sured by the glider in the upper $1000 \mathrm{~m}$ of typically 10 to $20 \mathrm{~cm} \mathrm{~s}^{-1}$. A good example of this association occurred in October during Transit 1, when a doming of the deep isopycnals between $10^{\circ}$ and $12.5^{\circ} \mathrm{W}$ and about $57^{\circ} \mathrm{N}$ coincided with a trough in the SLA and drove a strong south-westward current (Figs. 6 and 7).

\subsection{Interaction between glider track and mesoscale currents}

By the time the glider turned eastward from the Rockall Bank on 31 October (Transit 1, Fig. 6) the large cyclonic circulation $\mathrm{A}_{\mathrm{C}}$ had settled on the western side of the trough (Fig. 7a), which initially forced it southward along the western side of the circulation (west of $12.5^{\circ} \mathrm{W}$ in Transit 2). The glider was then carried eastward along the interface between the southern side of $A_{C}$ and the northern side of the anticyclone $\mathrm{B}_{\mathrm{A}}$ until it was picked up by the eastern side of this circulation and deflected south-eastward. The isopycnals at $1000 \mathrm{~m}$ in $\mathrm{B}_{\mathrm{A}}$ were by then significantly deeper than when $\mathrm{A}_{\mathrm{C}}$ occupied the eastern side of the trough (see also Fig. 10).

Until the end of December (Transit T3, Fig. 6) the subsurface isopycnal levels tended to mirror the sea surface undulations observed by the altimeters. However, from the end of Transit 2 (12 November) a deep water doming of the isopycnals appeared between about $9.5^{\circ}$ and $10.5^{\circ} \mathrm{W}$ that seems to have been associated with the presence of lighter water in the upper $300 \mathrm{~m}$ of the slope current, and is not readily reflected in the SLA. At this time the Aviso current speeds along the transits were at their maximum (and greater than those observed by the glider), but from then on until the end of the mission glider drift speeds (averaged over $1000 \mathrm{~m}$ )
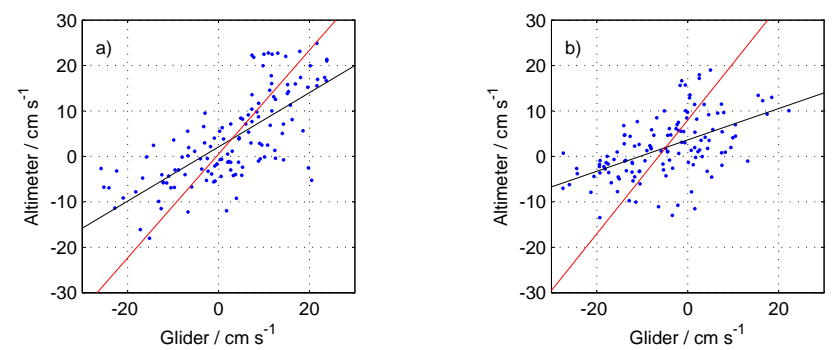

Figure 11. Scatter plot of glider vs. altimeter speeds; (a) east, (b) north. Correlation lines $\left(\mathrm{cm} \mathrm{s}^{-1}\right)$ are fitted to Aviso (black) and to the glider (red), and correspond to values in Table 2. Altimeter values have been interpolated in time and space to coincide with the glider observations.

were always 2 times greater than the surface altimeter speeds (Table 1).

In Transit 4 an uplift of deep isopycnals at about $9.8^{\circ} \mathrm{W}$ drove a southward current between $10^{\circ}$ and $10.5^{\circ} \mathrm{W}$ in response to the presence of a cold core that was most pronounced below $800 \mathrm{~m}$. Similar currents were found on the northern side of the Hebrides Terrace Seamount at about $56.5^{\circ} \mathrm{N}, 10^{\circ} \mathrm{W}$ in transits 7 and 8 (see Figs. $6 \mathrm{~b}$ and $7 \mathrm{f}$ ). The other transits also exhibited examples of doming of the deep water isopycnals driving glider drift currents that extended from the surface at least to $1000 \mathrm{~m}$.

\section{Direct comparison of the glider and altimeter current measurements}

\subsection{Comparison of individual observations}

The average current speed along individual tracks measured by the glider drift was often much greater that that observed by Aviso, particularly once the seasonal stratification had been eroded by the start of 2010 (Table 1) (during the June 2009 cruise the LADCP measured currents depth averaged to $1000 \mathrm{~m}$ were nearly twice as large as the equivalent Aviso surface currents; see also Table 1). Over the glider mission as a whole the eastward components of velocity were fairly closely correlated (0.69, Table 2 and Fig. 11a), whilst the correlation between the northward components was poorer (0.41 and Fig. 11b). One explanation may be the smoothing that is introduced by gridding the altimetry data, although the satellite altimeter coverage of the Rockall Trough was quite dense and smoothing would not explain the difference in correlation between the northward and eastward components of velocity. So these results are a little surprising and merit further investigation, particularly as there is some doubt about the accuracy of the geoid and MDT across slope regions (see Fig. 12a). 
Table 2. Values of the constants $C_{v}, m_{v}, C_{u}, m_{u}$ in the linear relationships between the glider drift $\left(u_{\mathrm{G}}, v_{\mathrm{G}}\right)$ and Aviso surface $\left(u_{\mathrm{A}}\right.$, $v_{\mathrm{A}}$ ), velocities $u_{\mathrm{A}}=C_{u}+m_{u} u_{\mathrm{G}}$ (eastward) and $v_{\mathrm{A}}=C_{v}+m_{v} v_{\mathrm{G}}$ (northward) along with the correlation coefficients, $R_{u}$ and $R_{v}$, and the number of observations, $n$. The fits to Aviso data (standard font) and glider data (bold font) are shown. The best fit will be somewhere between the two. There is a marked improvement in the correlation of the individual northward currents once $A_{\epsilon}$ is applied. Observations were smoothed over about 1 day with a four-point Hamming window and subsampled. The meridional averages are derived from the red and blue curves in Fig. $12 \mathrm{~b}$ and c.

\begin{tabular}{lrrrr|rrr}
\hline & & \multicolumn{3}{c|}{ Eastward } & \multicolumn{3}{c}{ Northward } \\
\cline { 3 - 8 } Transits & $n$ & $C_{u}$ & $m_{u}$ & $R_{u}$ & $C_{v}$ & $m_{v}$ & $R_{v}$ \\
\hline Meridional & 23 & 1.9 & 1.2 & 0.92 & 1.4 & 0.11 & 0.07 \\
averages & & $\mathbf{1 . 4}$ & $\mathbf{1 . 4}$ & & $\mathbf{1 2 0}$ & $\mathbf{2 5}$ & \\
\hline Individual & 128 & 3.9 & 0.70 & 0.69 & 3.7 & 0.36 & 0.41 \\
observations & & $\mathbf{1 . 6}$ & $\mathbf{1 . 5}$ & & $\mathbf{1 3}$ & $\mathbf{2 . 2}$ & \\
\hline With $A_{\epsilon}$ & 121 & 3.6 & 0.65 & 0.69 & 2.9 & 0.50 & 0.73 \\
correction & & $\mathbf{1 . 5}$ & $\mathbf{1 . 3}$ & & $\mathbf{5 . 4}$ & $\mathbf{1 . 0}$ & \\
\hline
\end{tabular}

\subsection{Correcting for errors in the MDT velocity field}

The extent to which the steady MDT velocity field (Fig. 12a) deviates from the true background velocity field in the Rockall Trough has been determined by averaging all the simultaneous glider and altimeter currents along all tracks into $10^{\prime}$ of longitude bins along a mean track, including those in transits 3 and 6 that were previously omitted, but ignoring velocities $>30 \mathrm{~cm} \mathrm{~s}^{-1}$ (see Fig. 5). The justification is outlined in Appendix A. It is important to note that the eastward (i.e. across-trough) components of the temporal mean velocities from the glider $\left(G_{\mathrm{M} 1}\right)$ and Aviso $\left(A_{\mathrm{M} 1}\right)$ are strongly correlated $(R=0.92$, Table 2$)$ with a constant of proportionality ( $\alpha$, Appendix A) that looks close to 1 in Fig. 12c. (The results of the correlation analysis in Table 2 suggest that $\alpha \sim 1.3$, but tests showed that the precise value of $\alpha$ is not critical.) On this basis it is also assumed that the true $\alpha$ equals 1 for northward currents and that the striking difference in the glider and Aviso measurements in this direction (Fig. 12b) can be attributed to errors in the MDT current field along the track $\left(A_{\in}\right)$. This error was calculated from Eq. (A5) with $\bar{U}+G_{\epsilon}$ set to 0 for convenience and is shown by the black lines and vectors in Fig. 12. The true background current $(U)$ can be estimated by mentally adding the black arrows to the blue MDT field arrows along the track in Fig. 11a. The two components of $A_{\in}$ were interpolated along the mean glider track and used to correct individual Aviso measurements (making no allowance for any variation of $A_{\in}$ with latitude). This improved the correlation between the corrected northward Aviso and glider currents from 0.41 to 0.73 (Table 2). The equivalent correction for the eastward currents did not improve the correlation (Fig. 10a and c), which suggests that most of the improvement in the northward compo- nent is due to the domination of the slope current error (see Fig. 12). Thus the MDT fails to produce the slope currents northward along the European edge and southward along the eastern flank of Rockall. Although the anomalous MDT current field to the south of the ADS appears to be robust (since the standard error in the estimates of the mean background current are small, Fig. 11), it can be explained when combined with the anomaly in the slope current. Taken together these anomalies suggest that the extensive anti-cyclonic cell northward and over the Hebrides Terrace Seamount is also an artefact of the MDT.

An order of magnitude estimate of $\bar{U}$ is needed to complete the analysis. The mean northward transport through the trough is probably between 0.7 and $3.7 \mathrm{~Sv}$ (Holliday et al., 2000) which, with a cross-sectional area $250 \mathrm{~km}$ wide and $1000 \mathrm{~m}$ deep, implies that $\bar{U}$ is between 0.3 and $1.5 \mathrm{~cm} \mathrm{~s}^{-1}$. A dashed line has been added to Fig. $12 \mathrm{~b}$ at the mean of these speeds to show a $y$ coordinate shift of $-0.9 \mathrm{~cm} \mathrm{~s}^{-1}$. With this adjustment it appears that from its western edge at about $9.7^{\circ} \mathrm{W}$ the mean European slope current builds in strength to about $13.5 \mathrm{~cm} \mathrm{~s}^{-1}$ above the $500 \mathrm{~m}$ isobath at $9.1^{\circ} \mathrm{W}$, which is comparable to the value quoted in Sect. 2. Westward of this longitude to a meridian southward of the western edge of the ADS at $11.4^{\circ} \mathrm{W}$ the mean flow is $\mathrm{S}$ or $\mathrm{SSW}$ with a maximum of about $6 \mathrm{~cm} \mathrm{~s}^{-1}$ at $10.5^{\circ} \mathrm{W}$. West again the mean current flows northward around the western side of the ADS with a mean speed of 3-4 $\mathrm{cm} \mathrm{s}^{-1}$. Finally, at the very western end of the track, on the eastern flank of Rockall, the mean Equatorward slope current is of order $5 \mathrm{~cm} \mathrm{~s}^{-1}$. The general agreement of this pattern with the schematic mean circulation pattern described in Ellett et al. (1986) provides confidence with this analysis. We note that this estimate of a mean northward slope current at $56.75^{\circ} \mathrm{N}$ was derived during a prolonged period with a weak current temporarily southward because the main current had been deflected to the west.

\section{Discussion}

The central Rockall Trough is populated by mesoscale eddies or cells that appear trapped in the deep water, where they push each other randomly around on timescales of months. They drive currents that extend to the surface, but because surface temperatures in winter are uniform, the impact of these eddies is masked from satellite temperature sensors. During the glider mission they had transient currents that, integrated over the top $1000 \mathrm{~m}$ of the water column, had a mean speed of about $15 \mathrm{~cm} \mathrm{~s}^{-1}$ (Table 1). It is clear from the glider $\sigma_{\mathrm{t}}$ profiles and sections (Fig. 6), and from the LADCP measurement of D340 (Fig. 4), that they also extend well below $1000 \mathrm{~m}$, the maximum depth range of the glider.

The cyclonic eddies seem to be too deep to be formed from the local wind stress curl or the slope current (which extends to only about $400 \mathrm{~m}$ ) and must have originated elsewhere either as part of a northern extension of the eddy field at the 

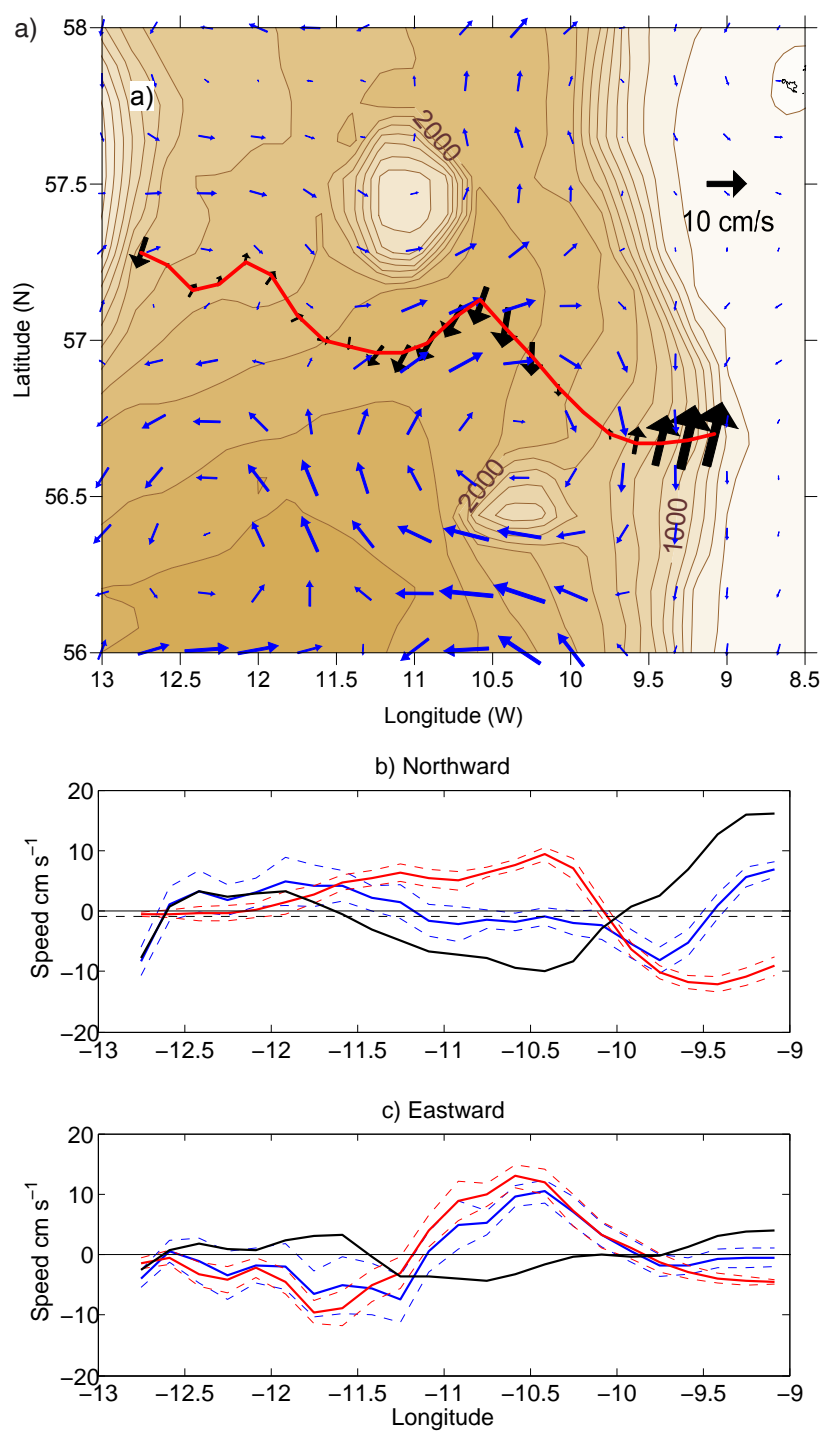

Figure 12. (a) MDT currents from Aviso (thin blue arrows) and mean absolute current along the glider track derived from (A5) (thick black arrows). (b) Northward and (c) eastward currents from simultaneous Aviso (red) and glider (blue) observations averaged over the whole mission into $10^{\prime}$ longitude bins, with the dashed lines being the standard error in the mean. The black lines are the difference between the Aviso currents that are displayed as vectors in (a). The lower horizontal line in (b) is an estimate of the offset of the $y$ axis origin to account for the mean current through the trough.

mouth of the trough, described by Ullgren and White (2012), or from the north (e.g. Ellett et al., 1983). The $1000 \mathrm{~m}$ profile dive limit and the fact that the glider did not get to the centre of a cyclonic eddy renders this discussion somewhat speculative. Profiles of $\theta S$ at the edges of cyclonic eddies $A_{C}$ and $F_{C}$ (Fig. 7), near the ADS, clearly have WTOW to $1000 \mathrm{~m}$ and may have been formed from intermittent bursts of cold water overflow across the Wyville Thomson Ridge (Ellett et al., 1983; Johnson et al., 2010; Sherwin et al., 2008).
The glider did not pass close to the cyclonic eddies south of the ADS, and it is not known where they originated, although it is quite likely that they were derived from instabilities of the North Atlantic Current front near the mouth of the trough. The warm core anti-cyclonic eddy $\mathrm{B}_{\mathrm{A}}$ comprises ENAW (Harvey, 1982), rather than MOW, to at least $800 \mathrm{~m}$, and may have been spun off from the northward flowing slope current somewhere south of the region (see Ullgren and White, 2010).

The amount and spatial extent of mesoscale variability in the Rockall Trough seems to have an impact on the stability of the northward propagating current slope current along the western edge of the European shelf, which has a mean speed of comparable magnitude $\left(\sim 15 \mathrm{~cm} \mathrm{~s}^{-1}\right)$. In some of the sections reported by Holliday et al. (2000) slope current water appears to be spread across the trough, and our observations seem to explain what is going on when that happens. The vertical profile of water west of the ADS, which at $500 \mathrm{~m}$ was much cooler and fresher than that to the east in June 2009, had become much warmer and saltier and adopted an eastern looking profile by February 2010 (Fig. 3). During the intervening period, starting around the beginning of December and continuing through to the end of February, there was a sustained period of north-westerly geostrophic flow extending from the Hebrides Terrace Seamount at $10.5^{\circ} \mathrm{W}, 56.5^{\circ} \mathrm{N}$ towards the Rockall Bank (Fig. 1 and D in Fig. 7). From the ADT plots the speed of this current was typically $20 \mathrm{~cm} \mathrm{~s}^{-1}$, so it would take of order 1 week to cross the trough. Using a width of this current from Fig. $7 \mathrm{~d}$ of $25 \mathrm{~km}$, and an assumed depth of $1000 \mathrm{~m}$, gives its rate of transport as $5 \mathrm{~Sv}$. A current of this magnitude, which is much larger that the ambient currents in the central trough, sustained over a period of 3 months, would certainly be big enough to explain the apparent excursion of slope current water away from the $\mathrm{Eu}-$ ropean side onto the Rockall side. This is taken as evidence that the mesoscale activity in the trough can lead to substantial horizontal exchange in the upper $1000 \mathrm{~m}$. Variable currents of this nature contribute to the inter-annual variability reported for the upper $800 \mathrm{~m}$ observations of temperature and salinity along the Ellett Line (Holliday et al., 2000; Sherwin et al., 2012) and also have sufficient magnitude to reverse the slope current for several months.

It is noted from the altimeter observations that there was a tendency for the mesoscale structures to become stuck in the vicinity of the local seamounts and, in particular, both anti-cyclonic (in November) and cyclonic (in February) eddies appeared to become trapped on the ADS. This is surprising given that the full vertical extent of these eddies is much deeper than the top of the seamount $(500 \mathrm{~m})$ and was not anticipated by Booth (1988), who suggested that Taylor columns form with closed streamlines over the ADS. Whilst both senses of circulation satisfy this requirement, there is no evidence that the seamount itself generated these eddies, or that cyclonic circulation is preferred over anti-cyclonic. 
It remains to add some final comments about the use of glider data in this investigation. It would not have been possible to undertake such a detailed description and analysis of the mesoscale variability without the repeated measurements of the in situ conditions in the Rockall Trough by the glider. Its $C \theta$ observations provided the information about the depth of the eddies, and the drift data, despite being compromised by a suspect compass, gave irrefutable evidence that the surface currents inferred from satellite altimetry should not be assumed to decrease with depth when the water column is mixed.

But this warning may only apply to currents with relatively short timescales because over longer timescales the two measurement systems seemed to observe currents of similar velocities. The apparent success of combining glider and gridded altimeter observations averaged over a 6 month period to determine the difference in the background mean currents suggests that glider observations may provide a practical methodology for improving the definition of the geoid in other regions where the existing MDT is not well defined.

The synergy derived from the combined use of glider and altimeter observations also provides valuable information about the state of a transient velocity field that can help glider pilots operating in the North Atlantic. Very often a glider will encounter an unexpected current, and reference to the contemporary gridded map of SLA or ADT can provide the pilot with valuable information for charting a course to avoid, or to make use of it.

\section{Conclusions}

The principal findings of this investigation are that

1. much of the surface and deep mesoscale current field in the central Rockall Trough is driven by deep circulations that appear to be associated with eddies that seem to have migrated into the region from both north and south;

2. surface currents appear to be much stronger during the autumnal period of seasonal stratification than in late winter, when the upper trough is mixed to a depth of $600 \mathrm{~m}$;

3. in late 2009, during a period of unusually large EKE activity, a deflection of the slope current, caused by a chance arrangement of some deep mesoscale features, resulted in a large quantity of slope water being advected to, and thereby warming, the upper $500 \mathrm{~m}$ of the western side of the trough; and

4. the background MDT field of the Aviso CNES-CLS09 data set fails to pick up the mean transport in the narrow slope currents either side of the Rockall Trough, and may also introduce a fictitious mean anti-cyclonic circulation north of the Hebrides Terrace Seamount. 
Appendix A: Deriving background mean currents along the glider track from altimeter and glider measurements

It is useful to define the true background current field across the Rockall Trough, $\bar{U}+U(x)$ defined below, and although neither the Aviso nor the glider velocity measurements can do this on their own, they can be combined to provide a credible result that throws light on the accuracy of the MDT current field. In theory Aviso current anomalies should be relative to $\bar{U}+U(x)$, but at present this is not possible because the MDT uses a poorly resolved measurement of the geoid. This appendix demonstrates that by computing the difference between the two measurement systems, suitably averaged over the period of Mission 1, it is possible to determine the error in the velocities of the MDT along the track and hence find $U(x)$ (if not $\bar{U}$ ). There are a couple of practical problems that have to be recognised: (i) Aviso measures surface currents, whilst the glider measures the mean over $1000 \mathrm{~m}$, and (ii) there is an unknown compass error in the glider that leads to a spurious mean current. In practise it turns out that these problems are not critical.

Assume that the true current normal to the mean glider track across the Rockall Trough $(x)$ is given by

$U(x, t)=\bar{U}+U(x)+u_{\mathrm{S}}(x, t)+u_{\mathrm{T}}(x, t)$,

where $\bar{U}$ is the mean current averaged across the trough; $U(x)$ is the steady anomaly to the mean current along the track; and $u_{\mathrm{S}}(x, t)$ and $u_{\mathrm{T}}(x, t)$ are respectively short-period and long-period velocity anomalies. Assume also that over the 6 month period of Mission $1 u_{\mathrm{S}}$ averages to zero, but that $u_{\mathrm{T}}$ integrates to a finite quantity $U_{\mathrm{M} 1}(x)$, the anomalous seasonal current during Mission 1 . The true mean velocity along the track for this period, $U_{\mathrm{M} 1}(x)$, is then given by

$U_{\mathrm{M} 1}(x)=\bar{U}+U(x)+U_{\mathrm{M} 1}(x)$.
The temporal averaged drift current measured by the glider is

$G_{\mathrm{M} 1}(x)=U_{\mathrm{M} 1}(x)+G_{\epsilon}$,

where $G_{\in}$ is the anomalous current due to the compass error (assumed uniform across the trough), and for clarity, any other errors in the glider measurements are small and average to zero.

The equivalent surface current measured from altimetry is simply

$A_{\mathrm{M} 1}(x)=\alpha U_{\mathrm{M} 1}(x)+A(x)$,

where $\alpha U_{\mathrm{M} 1}$ is derived from the ADT with $\alpha$ the ratio of Aviso surface velocities to the glider drift current; $A(x)$ is the mean current derived from the MDT; and other errors are assumed to be small and random. Note that because of the errors in the MDT, $A(x) \neq \bar{U}+U(x)$.

Assuming that $\alpha=1$ (see main text for a justification), then the difference between the two velocity fields is found by subtracting Eq. (A4) from Eq. (A3) and using Eq. (A2):

$G_{\mathrm{M} 1}(x)-A_{\mathrm{M} 1}(x)=\left[\bar{U}+G_{\in}\right]+[U(x)-A(x)]$.

The first term in square brackets comprises the mean current across the Rockall Trough plus the anomalous current due to the error in the glider compass. Both these currents are likely to be of similar order (a few $\mathrm{cm} \mathrm{s}^{-1}$ ) and cannot be separated, so it not possible to determine $\bar{U}$ directly from the present set of glider measurements. Other methods are possible (see main text). The second term in square brackets is the error in the mean current along the transit of the MDT, i.e. $A_{\epsilon}=U(x)-A(x)$.

If instead of using the ADT we use the SLA (i.e. set $A(x)=0)$ then $U(x)$ can be determined simply from Eq. (A5) and $U_{\mathrm{M} 1}(x)$ from Eq. (A4). The choice is arbitrary, but in the present case the ADT has been used so that the focus is on the error in the MDT currents along the track. 
Acknowledgements. The cost of the glider and its operation was funded by the UK NERC as part of its Oceans2025 programme, and the Ellett Line cruises are a NERC funded National Capability activity. This paper was written with support from NERC's FASTNEt research programme and is also an EU Framework 7 grant no. 308299 (NACLIM) publication. The altimeter products were produced by Ssalto/Duacs and distributed by Aviso, with support from CNES. The NAO data were acquired from the Climate Research Unit. The NLV Pole Star operated by the Northern Lighthouse Board made a prompt course diversion to recover the glider when it developed a technical problem in March. We are very grateful for the helpful support provided by Seaglider Fabrication before and during what was the first Seaglider mission operated by SAMS. Discussions with EU colleagues in Everyone's Gliding Observatories (EGO) also gave us confidence to undertake the mission. We are grateful for advice about the eddy water types from C. Johnson. None of this would have been possible without the dedicated support from a team of skilled technicians and students at SAMS. We are very grateful for the valuable comments provided by two anonymous referees which have resulted in an improved paper.

Dedication. This paper is dedicated to the memory of Tim Boyd, former friend, colleague and office mate, who was tragically killed in a freak accident in January 2013. Tim was fascinated by the display of Rockall Trough glider data that evolved in real time on my monitor and was poised to lead glider research at SAMS after I (T. J. Sherwin) retired.

Disclaimer. All data used here are freely available on the web. The AVISO products can be found at www.aviso.oceanobs.com/duacs and the glider and Ellett Line data at the British Oceanographic Data Centre (www.bodc.ac.uk).

Edited by: J. A. Johnson

\section{References}

Bacon, S.: Decadal variability in the outflow from the Nordic seas to the deep Atlantic Ocean, Nature, 394, 871-874, 1998.

Booth, D. A.: Eddies in the Rockall Trough, Oceanol. Acta, 11, 213-219, 1988.

Booth, D. A. and Ellett, D. J.: The Scottish continental-slope current, Cont. Shelf. Res., 2, 127-146, 1983.

Burrows, M., Thorpe, S. A., and Meldrum, D. T.: Dispersion over the Hebridean and Shetland shelves and slopes, Cont. Shelf. Res., 19, 49-55, 1999.

Dickson, R. R., Gould, W. J., Griffiths, C., Medler, K. J., and Gmitrowicz, E. M.: Seasonality in currents of the Rockall Channel, P. Roy. Soc. Edinb. B, 88, 103-125, 1986.

Ellett, D. J. and Martin, J. H. A.: The physical and chemical oceanography of the Rockall Channel, Deep-Sea Res., 20, 585$625,1973$.

Ellett, D. J. and Roberts, D.: The overflow of Norwegian Sea deep water across the Wyville-Thomson Ridge, Deep-Sea Res., 20, 819-835, 1973.
Ellett, D. J., Edwards, A., and Bowers, R.: The hydrography of the Rockall Channel - an overview, P. Roy. Soc. Edinb. B, 88, 61-81, 1986.

Ellett, D. J., Kruseman, P., Prangsma, G. J., Pollard, R. T., Van Aken, H. M., Edwards, A., Dooley, H. D., and Gould, W. J.: Water masses and mesoscale circulation of North Rockall Trough waters during JASIN 1978, Phil. Trans. R. Soc. Lond. A, 308, 213-252, 1983.

Eriksen, C. C., Osse, T. J., Light, R. D., Wen, T., Lehman, T. W., Sabin, P. L., Ballard, J. W., and Chiodi, A. M.: Seaglider: a longrange autonomous underwater vehicle for oceanographic research, IEEE J. Oceanic Eng., 26, 424-436, 2001.

Fratantoni, D. M.: North Atlantic surface circulation during the 1990's observed with satellite-tracked drifters, J. Geophys. Res., 106, 22067-22093, 2001.

Hakkinen, S. and Rhines, P.: Shifting surface currents in the northern North Atlantic Ocean, J. Geophys. Res., 114, C04005, doi:10.1029/2008JC004883, 2009.

Hansen, B. and Østerhus, S.: North Atlantic-Nordic Seas exchanges, Progr. Oceanogr., 45, 109-208, 2000.

Hansen, B., Hátún, H., Kristiansen, R., Olsen, S. M., and Østerhus, S.: Stability and forcing of the Iceland-Faroe inflow of water, heat, and salt to the Arctic, Ocean Sci., 6, 1013-1026, doi:10.5194/os-6-1013-2010, 2010.

Harvey, J.: Theta-S relationships and water masses in the eastern North Atlantic, Deep-Sea Res., 29, 1021-1033, 1982.

Hátún, H., Sando, A. B., Drange, H., Hansen, B., and Valdimarsson, H.: Influence of the Atlantic subploar gyre on the thermohaline circulation, Science, 309, 1841-1844, 2005.

Hátún, H., Eriksen, C. C., and Rhines, P. B.: Buoyant Eddies Entering the Labrador Sea Observed with Gliders and Altimetry, J. Phys. Oceanogr., 37, 2838-2854, 2007.

Heywood, K. J., McDonagh, E. L., and White, M. A.: Eddy kinetic energy of the North Atlantic Subpolar Gyre from satellite altimetry, J. Geophys. Res., 99, 22525-22539, 1994.

Holliday, N. P., Pollard, R. T., Read, J. F., and Leach, H.: Water mass properties and fluxes in the Rockall Trough, 1975-1998, Deep-Sea Res. Pt. I, 47, 1303-1332, 2000.

Holliday, N. P., Gary, S., Cunningham, C., Johnson, C., Griffiths, C., Read, J. F., and Sherwin, T.: Mulit-decadal varability of potential temperature, salinity and transport in the eastern Sub-polar Gyre North Atlantic, J. Geophys. Res., in review, 2015.

Hurrell, J. W.: Decadal trends in the North Atlantic Oscillation: regional temperatures and precipitation, Science, 269, 676-679, 1995.

Jakobsen, P. K., Ribergaard, M. H., Quadfasel, D., Schmith, T., and Hughes, C. W.: Near-surface circulation in the northern North Atlantic as inferred from Lagrangian drifters: variability from the mesoscale to interannual, J. Geophys. Res., 108, 3251, doi:10.1029/2002JC001554, 2003.

Johnson, C., Sherwin, T., Smythe-Wright, D., Shimmield, T., and Turrell, W.: Wyville Thomson Ridge overflow water: spatial and temporal distribution in the Rockall Trough, Deep-Sea Res. Pt. I, 57, 1153-1162, 2010.

Johnson, C., Inall, M., and Hakkinen, S.: Declining nutrient concentrations in the northeast Atlantic as a result of a weakening Subpolar Gyre, Deep-Sea Res. Pt. I, 82, 95-107, 2013. 
Lankhorst, M. and Zenk, W.: Lagrangian observations of the middepth and deep velocity fields of the northeastern Atlantic Ocean, J. Phys. Oceanogr., 36, 43-63, 2006.

Martin, J. P., Lee, C. M., Eriksen, C. C., Ladd, C., and Kachel, N. B.: Glider observations of kinematics in a Gulf of Alaska eddy, J. Geophys. Res.-Oceans, 114, C12021, doi:10.1029/2008JC005231, 2009.

McCartney, M. S. and Mauritzen, C.: On the origin of the warm inflow to the Nordic Seas, Prog. Oceanogr., 51, 125-214, 2001.

Merckelbach, L. M., Briggs, R. D., Smeed, D. A., and Griffiths, G.: Current measurements from autonomous underwater gliders, in: EEE/OES 9th Working Conference on Current Measurement Technology, Charleston, 17-19 March 2008, 61-67, 2008.

Perry, M. J., Sackmann, B. S., Eriksen, C. C., and Lee, C. M.: Seaglider observations of blooms and subsurface chlorophyll maxima off the Washington coast, Limnol. Oceanogr., 53, 21692179, 2008.

Pickart, R. S., Spall, M. A., Ribergaard, M. H., Moore, G. W. K., and Milliff, R. F.: Deep convection in the Irminger Sea forced by the Greenland tip jet, Nature, 424, 152-156, 2003.

Pollard, R. T., Guymer, T. H., and Taylor, P. K.: Summary of the JASIN 1978 field experiement, Philisophical Transactions of the Royal Society of London A, 308, 221-230, 1983.

Reid, J. L.: On the contribution of the Mediterranean Sea outflow to the Norwegian-Greenland Sea, Deep-Sea Res., 26, 1199-1223, 1979.

Rio, M. H., Guinehut, S., and Larnicol, G.: New CNES-CLS09 global mean dynamic topography computed from the combination of GRACE data, altimetry, and in situ measurements, J. Geophys. Res.-Oceans, 116, C07018, doi:10.1029/2010JC006505, 2011.

Sherwin, T. J., Griffiths, C. R., Inall, M. E., and Turrell, W. R.: Quantifying the overflow across the Wyville Thomson Ridge into the Rockall Trough, Deep-Sea Res. Pt. I, 55, 396-404, 2008.
Sherwin, T. J., Aldridge, D., Allen, J., Amin, S., Attard, K., Beaton, J., Brand, T., Barnard, C., Calderwood, J., Dumont, E., Hebden, M., Ivanov, V., Macey, A., Marsay, C., McLachlan, R., McRae, J., Mogg, A., Mohammed, K., Porter, M., Read, J., Rerolle, V., Richier, S., Short, J., Steigenberger, S., and Wager, N.: Cruise D340a: Reykjavik to Dunstaffnage via Rockall and the Wyville Thomson Ridge, Scottish Association of Marine Science, Oban, UK, 196 pp., 2009.

Sherwin, T. J., Read, J. F., Holliday, N. P., and Johnson, C.: The impact of changes in North Atlantic Gyre distribution on water mass characteristics in the Rockall Trough, ICES J. Mar. Sci., 69, 751-757, 2012.

Souza, A. J., Simpson, J. H., Harikrishnan, M., and Malarkey, J.: Flow structure and seasonality in the Hebridean slope current, Oceanol. Acta, 24, S63-S76, 2001.

Tett, S. B. F., Sherwin, T. J., Shravat, A., and Browne, O.: How much has the North Atlantic Ocean overturning circulation changed in the last 50 years?, J. Climate, 27, 6325-6342, 2014.

Thurnherr, A.: A practical assessment of the errors associated with full-depth LADCP profiles obtained using Teledyne RDI Workhorse acoustic Doppler current profilers, J. Atmos. Ocean. Tech., 27, 1215-1227, 2010.

Ullgren, J. and White, M.: Water mass interaction at intermediate depths in the southern Rockall Trough, northeastern North Atlantic, Deep-Sea Res. Pt. I, 57, 248-257, 2010.

Ullgren, J. and White, M.: Observations of mesoscale variability in the Rockall Trough, Deep-Sea Res. Pt. I, 64, 1-8, 2012.

Volkov, D. L.: Interannual variability of the altimetry-derived eddy field and surface circulation in the extratropical North Atlantic Ocean in 1993-2001, J. Phys. Oceanogr., 35, 405-426, 2005. 